\title{
IITS BTSARICPION OF COMPEIPIOR
}

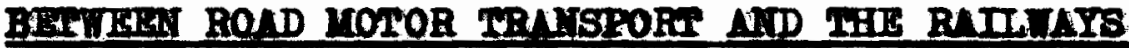

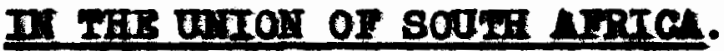

Thent for the degree of M.L. (Boonont os)

\author{
A. HORIIIZ.
}


The copyright of this thesis vests in the author. No quotation from it or information derived from it is to be published without full acknowledgement of the source. The thesis is to be used for private study or noncommercial research purposes only.

Published by the University of Cape Town (UCT) in terms of the non-exclusive license granted to UCT by the author. 
Bottom p. 25 and top p.26. Is it true that this section "prevente the use of discriminating monopoly power as between different

purchasera"? Cannot the "published tariff of charges" be discriminating?

( Cf. p.36 (middle) where he says "the tariff was so fixed as to eliminate the "undercutting of railway rates classified in the higher classes".) And would not the phrase "ordinarily makes under similar circumstances" probably allow different charges for different commoditieo - a distinction which might not be on the basis of cost?

p.26; Qy. impartiality.

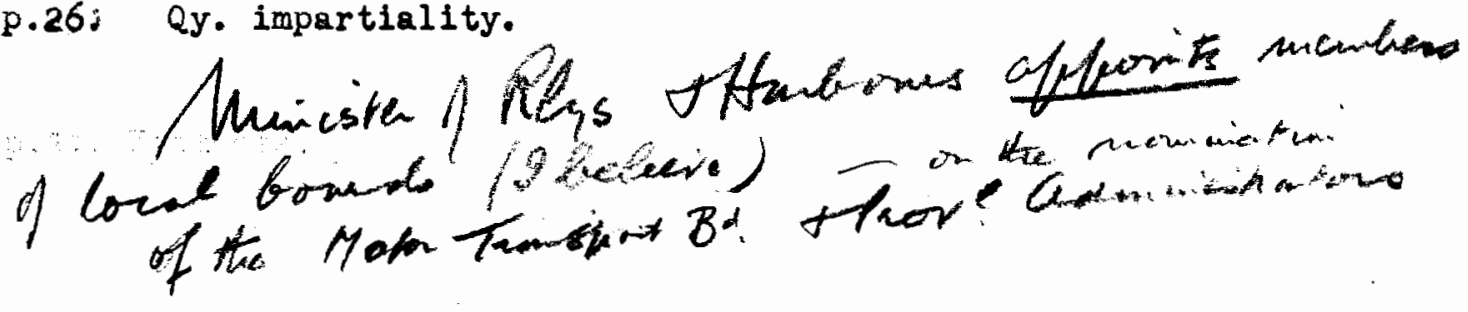

p.47. Does thio criticiom of depreciation tally with the modern theory (Fowler) which, if I interpret it correctly, auggests that plant of a huge organisation of this kind is likely to assume a condition in which plant is (permanently) on the average half worn out though fully efficient; that, therefore, a surplus would arise on depreciation account equal to approx. $50 \%$ of the amount originally invested by owners of capital; and that this 50\% (which represents ourplus capital) should be returned to the owners of capital as a return of capital. If this view is correct, may it not be wrong to call the surplus on depreciation account

"unnecesearily high and illegitimate contributions". (N.B. Horwitz includes Fowler's book in his bibliography)

p.50 (top). But is not the General Manager comparing the costof them

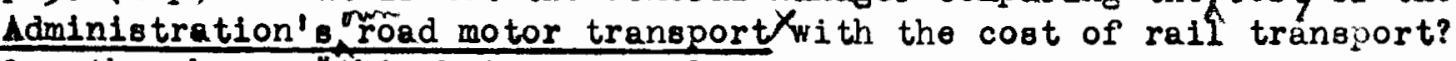
Qy. the phrase "this brings out clearly that road transport is not more economical than rail transport".

pp. 70 et seq. What is the special sanctity about getting an "output"? I can imegine the poseibility of millions of potential commodities which do not exist under competition, but each of which might come into being under discrimination. Muet we then divert resources in order to produce all these things (to the exclusion of other things)? or what is the criterion by which wo choose one or the other?

Neither have I ever been able to understand the argument that diecriminating monopoly is socially advantageous when decreasing cost operates. (And Horwitz does not explin this.) To bring a large capital unit into being in this way may possibly delay the invention of a smaller capital unit for producing a similar service. 


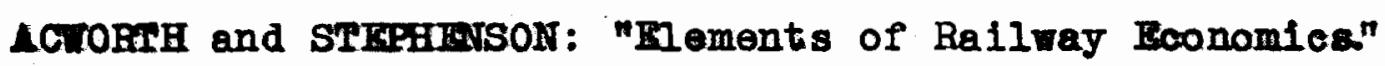
CHAMBRIIN: Monopolist10 Compet1tion:

Gisster: Tublie Control of Road Passenger Transport." Imakas: "Transport and the Pabl10."

Falkere: "Railway Polley of the Union of South Africa."

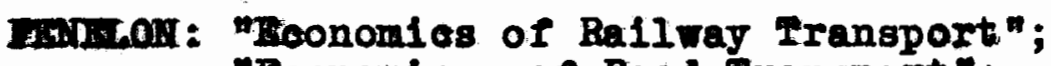

"Foonomilos of Boad Transport";

"Transport Corordination".

condrR: "Depreolation of Capital."

HOLMSTrOM: "Rallways \& Roads in Ploneer Development Orerseas."

IIICAT: "Wthios of Competition".

MRSHALL: "Industry and Trade"

MGIIR: "Covermmont Regalation of Railvay Rates".

MORRISON: "Socialisation and Transport".

PICOU: "Rooriomiles of Telfare".

HTLLT: Rallway Probleme."

SFMP: "Critlolem and Other Addresses."

TuSSIG: "il ments of Political Boonomy."

THAsKoI: "Unifled Transport Syatem of the U.S.S.R."

IIIIIU): "Eoonomics of Railwey Transport:

reHI and ABTHRECIA: "Rioed and Rall in Forty Countries."

Innual Report of the Ceneral Manager of the

South Lefican Rallways since I925.

Iridence and Report of the Road Motor Competition Commission.

Anmal Reports of the Road Transportation Board

Domintons Royal Commission on Road Rail Transport.

Degartmental Railway Tariffs Inquiry Committee, 1930.

Soath African Railways Tariff Book.

JOUPuTs: Foonomion;

Inglish Beonomic Journal;

al. Journal of Hoonomios; guarterly Journal of Beonomics;

Lodern Transport;

Notor Traneport. 
CONrHerms.

B1bllography:

Page. No.

InTERODUCTION

$1-7$

GALPPBR I: Boad Notor Transport Competition

with the Raliways Prior to 1830: -.- 8 - 17

CRAPIFR II: The Measures taken to meet Compe-

tition -

GHAPRR III: Railway Management \& Railway Rates

In South Africa-..... $44-61$

GHPPRR IV: Theory of Rallway Rates -

CHAPRR V: TasteruI Competition"

CHUPFR VI: "Th Iroess of Publlo Heeds"

CHAPIFR VII: Some General Considerations. -...- $90-99$

CHAPTiR VIII: Conolusion

APPIAIIX I: -

Hote. 


\section{IMTRODUGIOA.}

The present phase in that long story of the provision of the essentiel sociel service of transportation is one which is of particular interest to the coonomie theorist as vell as to the economio historian. Over a perlod of less than half-a-century the entomobile industry hes made enormous progress. It has, hoverer, been only in the last trenty years that the orribus and the larry have atemmed the trend of a century and once again asserted the power of the road as opposed to the rail.

During the elghteenth century the cenal began to draw traffio from the road; in its turn the cenal was ouperseded by the railway and to-day it is the railway which has to Iight against the competition of the road the weel has turned full eyole.

Whe rapid succession of cost-reducing developments, which hero oharacterlsed the growth of road transport since the Mar, has been accompaniod by a generel apprehension that the rate and degree of obsolescence thereby sustained by already existing forms of tranepart involve some degree of 'waste', the aroidance of with is only possible by some form of legally enforeed protection; and that the more millions of pound that are inom to have been intested in the older forms of transport, the more deserving are they of some speatal dispensation from the otherwise ineritable consequences of such derelopments. 1 .

This problew, then, of the competition of roed notor carrior with the older established transportation service/.. 
service has beecme the dadient reature of the transport induatry in almost every oivilised country. Progress seened addienly to have beoome wasterul and Iogislatives decued it necessary to cheok this 'wasterul progress' by the enforcenment of reatrietive meenures on the advance of rond ntor transport. Inis essay is an attempt to sarrey the position in South irrica to-day and as an Intreduction to this study, it is interesting to note brlefly the rarlons attempte made in other countrles to deal ifth the same problem.

The following table, taken from an articlo by Frof. H. 4. Eallaworth on the Iuture of Rall Transport", mows the ceoline in recolpts and expeaditure on certain Irropean railraya.

TABTE I.

\begin{tabular}{|c|c|c|c|c|c|}
\hline $\begin{array}{l}\text { AILWAY OR } \\
\text { COUNTRY }\end{array}$ & $\begin{array}{l}1929 \\
\text { Housands }\end{array}$ & $\begin{array}{l}1930 \\
\text { Housands }\end{array}$ & $\begin{array}{c}1931 \\
\text { thousands }\end{array}$ & $\begin{array}{l}1932 \\
\text { Housands }\end{array}$ & $\begin{array}{l}1933 \\
\text { Housands }\end{array}$ \\
\hline $\begin{array}{l}\text { Belgian } \\
\text { National Rily }\end{array}$ & $\begin{array}{|cc|}\text { BELGIAN REC. 3,546,695 } \\
\text { FRANCS } & \text { EXP. 3,066,823 }\end{array}$ & $\begin{array}{l}3,528,540 \\
3,208,358\end{array}$ & $\begin{array}{l}3,090,730 \\
3,023,944\end{array}$ & $\begin{array}{l}2,451,978 \\
2,620,480\end{array}$ & $\begin{array}{l}2,329,917 \\
2,342,960\end{array}$ \\
\hline $\begin{array}{l}\text { Czecko-Slovak } \\
\text { State Rly. }\end{array}$ & $\begin{array}{l}\text { CZECHO- REC } 4,888,543 \\
\text { SLOVAK } \\
\text { CROWNS EKP. } 4,447,197\end{array}$ & $\begin{array}{l}4,628,512 \\
4,521,131 \\
\end{array}$ & $\begin{array}{l}4,362,974 \\
4,183,938 \\
\end{array}$ & $\begin{array}{l}3,490,352 \\
4,043,031\end{array}$ & $\begin{array}{c}3,135,516 \\
x\end{array}$ \\
\hline $\begin{array}{l}\text { FRANCE } \\
\text { MAIN LINE RLYS. }\end{array}$ & $\begin{aligned} & \text { FRENCH } \text { RAC. } 16,110,142 \\
& \text { FRANCS } \text { EXP. } 12,669,028 \\
&\end{aligned}$ & $\begin{array}{l}16,032,040 \\
14,159,737 \\
\end{array}$ & $\begin{array}{l}14,584,578 \\
13,902,798 \\
\end{array}$ & $\begin{array}{r}12,428,809 \\
12,797,349\end{array}$ & $\begin{array}{l}11,707,912 \\
12,197,912\end{array}$ \\
\hline $\begin{array}{c}\text { GERMAN } \\
R L Y .\end{array}$ & $\begin{array}{ll}\text { GERMAN } & \text { REC } 5,353,834 \\
\text { MARKS } & \text { EXP } 4,493,496 \\
\end{array}$ & $\begin{array}{l}4,570,317 \\
4,090,353 \\
\end{array}$ & $\begin{array}{l}3,848,667 \\
3,622,471\end{array}$ & $\begin{array}{l}2,934,318 \\
3,001,084\end{array}$ & $\begin{array}{l}2,915,100 \\
3,063,000\end{array}$ \\
\hline $\begin{array}{l}\text { GT. BRITAIN } \\
\text { MAIN LINE RLY. }\end{array}$ & $\begin{array}{rr}\text { STERLING REC. } & 182,777 \\
\text { ENP. } & 143,698 \\
\end{array}$ & $\begin{array}{l}172,618 \\
139,483\end{array}$ & $\begin{array}{r}158,496 \\
128,541\end{array}$ & $\begin{array}{l}145,342 \\
121,336\end{array}$ & $\begin{array}{l}145,281 \\
119,355\end{array}$ \\
\hline $\begin{array}{l}\text { ITALIAN } \\
\text { STATE RLY }\end{array}$ & $\begin{array}{ll}\text { LIREE } & \text { REC. } 4,980,704 \\
\text { EXP. } 4,379,832 \\
\end{array}$ & $\begin{array}{l}4,600,066 \\
4,124,3 \% 0\end{array}$ & $\begin{array}{l}3,853,470 \\
3,573,490 \\
\end{array}$ & $\begin{array}{l}3,345,822 \\
3,218,465\end{array}$ & $\begin{array}{l}3,055,854 \\
3,190,138\end{array}$ \\
\hline $\begin{array}{l}\text { Jugo-SLAV } \\
\text { State RLYS. }\end{array}$ & $\begin{array}{ll}\text { DINAR REC } 2,680,313 \\
\text { EXP. } 2,688,422 \\
\end{array}$ & $\begin{array}{l}2,655,290 \\
2,732,332 \\
\end{array}$ & $\begin{array}{l}2,382,009 \\
2,542,506\end{array}$ & $\begin{array}{l}1,975,811 \\
2,069,390\end{array}$ & $\begin{array}{l}1,907,456 \\
1,922,236 \\
\end{array}$ \\
\hline $\begin{array}{l}\text { Polish } \\
\text { State RLYS }\end{array}$ & $\begin{array}{l}\text { REC. } 1,596,906 \\
\text { ELOTY } 1,413,894\end{array}$ & $\begin{array}{l}1,458,874 \\
1,331,520\end{array}$ & $\begin{array}{l}1,293,998 \\
1,187,306\end{array}$ & $\begin{array}{r}1,009,126 \\
936,014\end{array}$ & $\begin{array}{l}868,000 \\
810,700\end{array}$ \\
\hline $\begin{array}{l}\text { SWE DISH } \\
\text { STATE RLYS. }\end{array}$ & $\begin{array}{l}\text { SWEDISH REC } 208,130 \\
\text { CROWNS EXP. } 158,870\end{array}$ & $\begin{array}{l}201,580 \\
15 \%, 370 \\
\end{array}$ & $\begin{array}{l}181,230 \\
156,640 \\
\end{array}$ & $\begin{array}{l}166,140 \\
153,290\end{array}$ & $\begin{array}{l}166,140 \\
150,170\end{array}$ \\
\hline $\begin{array}{l}\text { SWISS } \\
\text { FEDERAL RLYS }\end{array}$ & $\begin{array}{l}\text { SWISS REC } 431,357 \\
\text { FRANCS ERP } 280,382\end{array}$ & $\begin{array}{l}420,546 \\
291,420\end{array}$ & $\begin{array}{l}389,450 \\
283,282\end{array}$ & $\begin{array}{l}342,953 \\
273,301\end{array}$ & $\begin{array}{l}335,844 \\
262,566\end{array}$ \\
\hline
\end{tabular}

1. The Foonomite Journal Deo. 1934 p.540 Table III. 
The canse of this fall in recolpts has not, of course, been solely that of the competition of the roads; the Industrial dopressian and the shrinicage in international trade have been perhapa more important factors, jot it cannot be gainsald that the inroads which the motor carrier has been makting into the trafelo of the rallway has had eerlous effects on the revenues of almost every railway eratien in the rorld.

In Ingland the f1rst logislatire step taken to meet the position oreated by this direreion of traffic was the passing of the load lot in 1030. It provided, anongst other things, for the fing of madman welght and dimansions for vehiales and for cempulwory insurance agatnat third party riaks. In regard to passenger tranoport, the Aree Traffic Commissioners were emporered to determine whether a cervice shall operate or nat considering the requiroments of the area served. Ls a result of the Salter Beport - the Repart of the Conference on Boad and Bail Irenzport, the Boad and Ball Irafflo Bill was enacted in 1933. Under this let a 110ence to operate met be obtained before a wator transport service cen be operated. There are three tjpes of liconce deatenated by the letters $A, B$ and $G$. The first, or Public Garrier's Ifeence, mat be obtained by carrlers transporting goods for third parties; the second, or Ifmited Carrier's If cence applies to rehioles carrying goods either in comeetion with the ormer's business or for bire or reward (It is ralid for only one jearl; the third apples to mourwetarere or enterpriaes using thefr own vehtcles for thefr ofn purposes. Part II of the lot entitled the rallwaye to grant epeoilel 'agreed' rates to any trader after approval by the Rates Irtbunal. L Transport Ldvisory Council to advise the cinister on questions of transport 
co-oralination has been establ1shed.

In Fingland the arowed parpose of legdalative intertarenoe has been to make the conditions, under whioh the two forms of transport operate, more equitable. The progress of fond trensport is not to be hampered but oompetition is to take place on a 'fair basis'. The rallwass, howerer, seem to herve found the 'solution' by themselves acquiring large interests in the roed transport industry. in eqtation is still proceeding for further protection of the railwajs and for some restrietion to be pleced on the use of their om transport by traders.

In the Unfted States of Amerfoe no contral is exarefsed through Foderal legelation though in individual states restrictire measures of vary ing effectiveness have been Introduced. Certainly it seems that in the United states, which is the home of the motor industry, Iars designed to ourtail the sphere of userulness of the motor car rould be impolitio. Both the Inter-State Comeree Commision (I932) and the Joint Committeo of Ballroad and HIfhways Users, however, cane to the seme generaI conelusions - that there is en exoess of carrying expacity of existing transport faclitiles due to competition of road transport under unequal conditions and that Federal regulation should provide for special authorisation of motor tranoport compantes and that frolght forwarding compantes and express rrelght companies should be made abject to the Inter-State commerce Act. (I have been unable to aseertain wether any leglolation has been passed to implement these recommendations.)

In France conditlons of road and rall transport co-ordination are governed by logislation aimed at a aultable epportioment of trafflo between the ret lways and motor transport respectively. This is aohieved mainly by roluntary regional agreements betreen representatires 
of the two forme of transport. The public authoritie aot as arbitrators when differences arlse end when no agreement is reached the arbitrator sumite proposals to the Minister for the modiffeation or suppression of exfiting sertices or, in some oases, for the establishment of net servlces.

In Cormany the sharp deoline in rail ray revenue during the ffre years before 1931 resulted in an emergenoy decree being brought Into operation on November I, 1931, destgred to regulate both passenger and goods transportat1on. Passenger tranport undertakings have to be senctioned by provincial authorities, who mat consider the views of other transport suppliers and of the Chmbers of Commeree. Coode traffic up to a distance of 50 klos. can be conveyed without any retrictions, but all goods serviees over creater distanoes have to be licensed. The operator is required to adhere to a fred uniform tariff which applies throughout the country and is framed so as to eliminate those concerns who had previously succeeded in capturing traffic from the rallways by syotematic underoutting. It seems most lfikely that under the present regime in Germany this restriction rould have been extended further rather than relaxed.

In Gzeohosiovakis all road transport undertalengs, passenger or goods, hare to obtain conoessions to operate. Ho ocncessions are grented which authorise competition with the State-omed raflrays or postal services. In Lastria, also, application to engage in the business of transport mat be made to the state authorities and such applications mat be firet referred to the railways, the poatal authorfties and the maicipal authoritios for thoir consideration. The flrat two have the right to institute the proposed service themselves, in wich case the application is, or course, refused. 
of the two forms of transport. The public authoritie act as arbitrators when differences arise and when no egreement is reached the arbitrator albute proposals to the Minister for the modifleation or appression of exteting sertioes or, in some oases, for the osteblishment of ner serrlces. In Cormany the sharp deeline in rell ray revenue during the ffre years before 1831 resulted in an emergenoy deeree being brought into operation on November 1 , 1931, cealgned to regulate both passenger and goods transportation. Passenger trangport undertakings heve to be sanctloned by provinclal authorities, who mast consider the viers of other transpart appliers and of the Chambers of Cameree. Coode traflio up to a distance of $50 \mathrm{kl} 10 \mathrm{~s}$. cen be conveyed without enj retrletions, but all goods nerviees orer greater distances have to be licensed. The operator is required to adhere to a plad uniform teriff which applies throughout the country and is framed so as to eliminate those concerns who had previousiy ancoeeded in capturing traffic from the rallrays by eystematic underoutting. It seems most likely that under the present regimo in Germany this restrietion rould have been extonded further rather than relaxed.

In Gzeahosiovakie all road transport undertakings, paseanger or goods, have to obtain conoessions to operate. No concessions are granted which euthorise competition wth the state-omed raflways or postal services. In Instria, also, application to engage in the business of transport at be made to the state authorities and ach applioations mat be Iret referredto the raflays, the postal athoritios and the mulolpal authorities for their consideration. The firat two have the right to institute the proposed serrice themselres, in wich case the application is, of course, refused. 
In Japen even more stringent control of the motor transport industry is practised. Commerolal transport services are placed under the control of the Rallway Department, a State Department, and all applications to apen a new service mast be made to it. In fact the state railway athorities regard motor transport as purely an auxillary servioe of the railraye.

In Australia the position can be illustrated by reference to Victoria. The Trensport Regulation let of 1833 established a Tranport Board with regulative porers. Commercial goods rehicles had to be llcensed by this authority. Such licences were to be issued 'as of right' to goods rehicles operating within a 25 miles radiue of certaln of the bigger eftIes such as Melbourne or Ballarat district; operating within a 20 miles' radius from the ormer's place of business; ormed by a primary producer under certain conditions, etc. In issuing or rerusing a Ilcence the Board is to have regard 'to the interest of the public generally, including those of persons requiring as well as those of persons providing transport facilities'. This brief survey of the messures taken in various countries to restriot the effectiveness of competition seems very etrong evidence in justification of the polfoy adopted in south Africa. It is indicative, hoverer, merely of the wide-spread nature of fallacious reasoning on this question.

In South Irica, is in other countries where the reilways are State-omed, the issue of the road rersus rail question is somewhat simplified. In such eiroumstances were the rallways are the property of the people it is proper to fudge the protection given to the railrays solely by the criteria of the public interest. In this ocuntry there are no vested interests of ormership which might be justification for placing restriations on the operation of 
private transport agencies.

In Capter 1 some indicetion will be given of the extent of road motor competition with the railways prior to the enactment of the Motor Carrier Regulation Acts. The provisions of the principal Act and the amending Acts will be given in some detail and an investigation made into how far competition has been eliminated. The remaining part of the essey will deal with the theory of the problem. In this seotion some consideration will be given to the management of the South African Railways and to its rating poliay. In conclusion certain suggestions will be.put forwerd to secure o cheap, efficient service of transportation. It must be noted that this thesis deals with the elimination of competitive private road operators $1 . e$. it will not discuss the substitution of road motor servioe for railway branoh lines by the S.A.R. itself. 
ROAD MOTOR TRANSPORT COMPEIIPION VITH THE RLIITTAYS PRIOR TO 1930:-

Unfortunately there are no detailed statistics arailable to 11lustrate exectly to what extent tho South African Ballways were efreated by the competition of private road motor carriers. Date regarding the tomnage of goods conveyed and number of passengers carrled by road transport before 1930 are not ascertainable. 4 consideration of the anmual reports of the General Manager of the S.N.R. and the references to the competition of private road operators therein is, however, enlightening.

In his report for the year ended 3lst larch, 1926, there appears a general statement that the Ballwey Administration has to contend with competition from road transport agencles. In his report for the following year, the coneral Hanager announced that competition 'may be considered as having reached the stage where it threatens vitally to feoperdise state interests. ...... Vy view is that the problem of road motor compatition in its relationship to our railways should be attacked woleheartediy and without delay. Otherwise there is considerable danger that the Aministration's finanoiel postion may bo rery serlously impaired." 1 .

Fron the report for 1928 it seems as if the revenues of the diministretion were being markediy arfeoted.

The situation oreated by the growth of road motor competition is becoming more and more acute es time goes an, and has giren rise to mach concern as there is no 
doubt that the railways are being deprived of an appreolable amount of their legitimate traffic.

"Passenger transport has been most serfously affected. On the Capetom-nymberg seotion, the number of passengers travelling is now about 270,000 fewer per month than was the case a few years ago, and the loss of traffic on the Sea Point line is also serlous. Road traffic has increased considerably between Capetown and Bellville, and Somerset West and the Strand. Competition with the Administration's rail pessenger services is also taking place on other systems, for instance, between Durban and Pletermaritzburg, on the North and South coast lines of Natal, as well as on many of the branch Iines; and in the suburban areas of Pretoria kast London and Port Flizabeth.

"As far as goods services are concerned, the prinolpal points of competition are in areas in which there are large distributing oentres. From Capetom, for instance, private road services radite to simonstown, Stellenbosch, Plquetberg, Vorcester, Robertson and even to Bredasdorp. Some are regular services, others are occasional. In the Cape Midlands there is competition between Port Flizabeth and Uitenhage, and Mossel Bay and Oudtshoorn. The Natal system has to contend with competition between Durban and Pietermaritzburg, Piversdale and Harrismith, and many locel services such as to Verulam and Stanger. In the Pransvaal road services are chlefly in evidence in the Tohannesburg and Pretoria areas." 1.

Next year the taking-up of the sea Point line is noted. nall efforts to inorease the popularity of the see Point line proved unavalling .... By the ond of the year 1928 the rate of loss of working had increased to approximately 247,000 p.a." 2 .

The/..

1. U.G. 54, 1928, pp. I3, 14.

Z. U.G. 50, 1929, p. 21 . 
The General Manager also points out that the introduction of a fast, frequent ond effloient eleotric train sertice from Gapetom to simonstom has still failed to aheak the diversion of passengers. (One would Iike to knot why the suburben residents were so obtuse as not to take adrentage of these faclitities.|

"Buring the elght months before electrifleation the Ioss on the Simonstom line was at the rate of $196,000,000$ p.a., the loss under eleotrio woriding for eight months was at the rate of $2215,000 \mathrm{p.a}$, and the total loss for the twelve months ending 0otober, 1929, was computed at 2250,000 ." I. The ohief oompetitive factors with which the Ballway Idninistration had to contend vere (I) private cars (II) taxis (111) omalbus services (IV) oharabeno servides (V) tramay eervices (VI) motor lorries omed by traders and firms (VII) motor trenepart compenles (Viil) farmers' motor transport (1x) ox and donkey wagons.

LET II.

LOTOR VWAICLS IICHASED IN THE UNION : 1933-1936. 2.

\begin{tabular}{|c|c|c|c|c|c|c|}
\hline ear & Cape & $\begin{array}{l}\text { MO } \\
\text { Nat }\end{array}$ & $\begin{array}{l}\mathrm{CA} \\
\mathrm{Tr}\end{array}$ & $0 . \mathrm{F}$ & Union & $\begin{array}{l}\text { \% Increase } \\
\text { orer prentous } \\
\text { rear. }\end{array}$ \\
\hline $\begin{array}{l}1923 \\
1924 \\
1925 \\
1986 \\
1927 \\
1989 \\
1989 \\
1930 \\
1931 \\
1938 \\
1985 \\
198\end{array}$ & $\begin{array}{l}55,800 \\
47,600 \\
59,509 \\
56,604 \\
57,607 \\
57,354 \\
56,001 \\
59,497 \\
69,288 \\
78,600\end{array}$ & 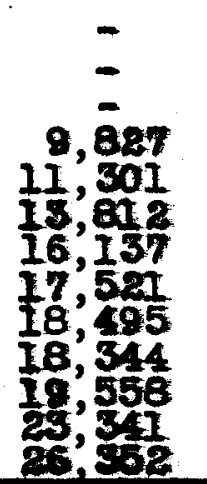 & $\begin{array}{c}\overline{-} \\
\overline{25}, 812 \\
29,338 \\
31,813 \\
31,888 \\
45,713 \\
45,855 \\
52,126 \\
58,673 \\
72,054 \\
85,081\end{array}$ & $\begin{array}{c}= \\
\overline{1} \\
11,500 \\
13,780 \\
15,702 \\
17,351 \\
17,786 \\
16,388 \\
16,864 \\
16,780 \\
18,872 \\
21,712\end{array}$ & $\begin{array}{r}38,815 \\
50,418 \\
63,030 \\
80,347 \\
96,019 \\
113,008 \\
130,560 \\
135,177 \\
138,078 \\
143,335 \\
153,503 \\
184,555 \\
212,767\end{array}$ & $\begin{array}{r}- \\
29.90 \\
25.01 \\
24.47 \\
19.51 \\
17.69 \\
15.36 \\
3.70 \\
2.19 \\
3.79 \\
7.09 \\
20.23 \\
15.29\end{array}$ \\
\hline $\begin{array}{l}1983 \\
1984 \\
1925 \\
1926 \\
1982 \\
1982 \\
1930 \\
1931 \\
1958 \\
1933\end{array}$ & $\begin{array}{r}z \\
z, \overline{105} \\
3,192 \\
6,235 \\
7,758 \\
8,602 \\
8,248 \\
8,812 \\
8,891 \\
11,052 \\
12,523\end{array}$ & 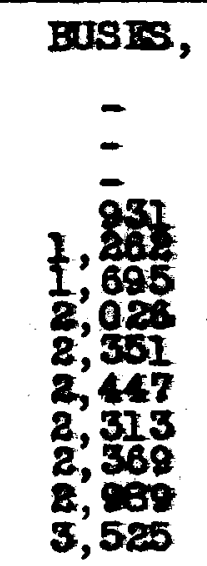 & 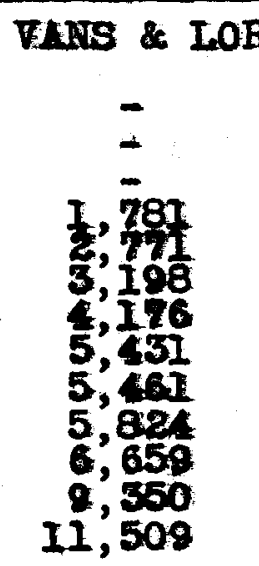 & $\begin{array}{r}795 \\
992 \\
541 \\
1,023 \\
846 \\
845 \\
910 \\
1,178 \\
I, 381\end{array}$ & $\begin{array}{r}1,989 \\
3,399 \\
4,258 \\
6,999 \\
8,897 \\
11,672 \\
14,769 \\
17,107 \\
18,176 \\
17,894 \\
18,859 \\
24,540 \\
28,938\end{array}$ & $\begin{array}{c}\text { Tincrease } \\
\text { or Deorease } \\
- \\
67.02 \\
88.18 \\
63.07 \\
16.04 \\
31.19 \\
26.53 \\
17.86 \\
4.42 \\
-1.55 \\
5.39 \\
30.17 \\
17.88\end{array}$ \\
\hline
\end{tabular}

2. Obtained Irom Year Books, Cape Argus. 
These Nigures show that oompetition from the private ar, text, onnibas and lorry mut have boen tonding to Inarease unth 1950. The rall in the rate of Inorense in private cars and taxis for the mext rour jears was due almost entirely to the serrese trace depression, bat the rall in the rate for bases and $10 r$ fles was in part due to the eneotment of restriotive legialation. The Fising flgares for the jears 1934 ard 1935 are indloative of the strong reviral in trade conditions in this country.

In inneance $B$ of the Memorandwn submitted by the Ceneral Innager of the S.A.R. to the Boad Motor Competition Comaciosion (1989), a detalled statement is giren showing the ereas in which competition axisted with the services of the laministration. 1.

The Cape Nestern syatem suffered both from passenger and goods competition. Fessenger transport companies rere perticulariy active on the routes:- Capetorn-See Point Camps Bay; Capetonn-Obeervatory-lymberg-1utzenberg; Bepetom-Iowiony-Lthlone; Capetom-Yattland-Ballville; Qxpetom-IIInerton; Bomerset Neat-Strand; GrearaterGandIlim-Galrinia; Toroester-Filliersdorp-Dgin; Coude-Porterville. On branch lines parties of people combinca to hire care - in partioular many excaraion parties of coloured people used hired lorries instead of the raliways. It was predioted that competition would Inerease on the routes:- Cupetorn-False Bay resorts;

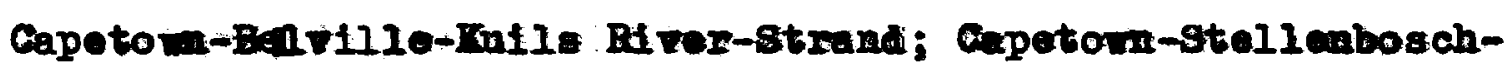
Farel and Copetom-italmeabury.

is regards goods trafflo, in the Gape Peninsula almost all the higher-rated traffio is now boling handlea by read; the districta mainly affected beyond the Peninsula area being:- Capotom-ralnesbury-I guetberg; Capetom-Kuils Aver-Strand-Caledon-Brodaca IP: Capatom-Paarl-Bugnonot- 
Mellington-Woreester; Gapetom-Stellenbosch; CapetomnRobertson; Hutchinson-Loxton. Ho regular services are operated but goods are transported when traffic offers.' In the Cape Fastorn system passenger services were operated between Bast Iondon-Kingwilliemstow; Fast IondonCambridge; Tarkastad-Gradook; Past London to stations in the Transkefan romiterles and to Molear. These cervices were minly for natives. I considerable mount of the petral trafric fram East Iondon to Butterworth, Idutyre, Umtata and other places in the Transketan Territories passed by road.

In the Cape Midland and Cape Northern systems, the competition was not serious though in Port Flizabeth suburban area passenger services were ective and large quantities of petrol rere conveyed from Noseel Bay to Oudshoorn by road.

In the Hatal system in the Durban area passengers and goods were conveyed between Durban-Hillerest; DurbanCavendial Durban-Clatmood-Jacobs; Durban-Isipingo-TerulanStanger; Durben-Umgeni-ut. Fdgecombe. On the main ine goods and pessenger competition was strong from Durban to Maritzburg and to Harriamith (goods) and from Umlaas BoadMarltzburg (passenger).

In the Free State system pessenger services operated between Philippalis V111age-Springfontein; JagersfonteinTrompsbërg; Jagersfontein-Fuu reamith; Reltz-Petrus Steyn; Thounissen-Tinburg; Petrus Steyn-Bethlehem; Patrus SteymIfindiey Road.

In the Testern Transvael system there were Buropean bus passenger services between Johannesburg-Germiston; Johannesburg-Main Reer; Johannesburg-Modderfontein Dynemite Pectory; BenonI-LIl1ance; Benoni-Geduld; Benonf-Brakpan; 
Springs-Largo Collierles; Krugersdorp-Robinson; Cormiston-

Handafontein-Flsburg; Cermiston-Fdenvale. During holidays and on Sundays prirate bus compenies arranged excursions between Johannesburg and points of interest in the Transvaal, such as Pretoria, Hartebeestpoort Dam, Vereeniging. Goods traffic was conveyed betreen Johannesburg and Rivonia and petrol between Sandopruit-imerspoort.

In the Rastern Transvaal syatem there was strong passenger competition in the Pretoria suburban area and cerere goods trafflc competition between Pretorie and Johannesburg.

\section{QUETE III.}

No. of Ordinary Passenger Booklnge on suburben Iines, 1924-30.

\begin{tabular}{|c|c|c|c|c|c|c|c|}
\hline & CLASS & $1924-25$ & $1925-26$ & $2926-27$ & $1927-28$ & $1928-29$ & $1929-30$ \\
\hline $\begin{array}{l}\text { CAPE TOWN } \\
\text { SUBURBAN AREA }\end{array}$ & $\begin{array}{l}\text { Total } \\
\text { allclasses }\end{array}$ & $9,268,338$ & $9,925,954$ & $9,750,965$ & $9,447,595$ & $9,286,689$ & $7,935,139$ \\
\hline $\begin{array}{l}\text { PORT } \\
\text { ELIZABETH }\end{array}$ & " & 835,145 & 798,232 & 819,302 & 810,248 & 743,218 & 664,189 \\
\hline $\begin{array}{l}\text { EAST } \\
\text { LONDON }\end{array}$ & $\because$ & 283,125 & 306,677 & 323,208 & 336,858 & 276,110 & 275,893 \\
\hline JOHANNESBURG & . & $5,618,196$ & $6,022,196$ & $5,908,373$ & $5,934,316$ & $6,019,377$ & $6,073,358$ \\
\hline PRETORIA & " & 741,847 & 842,969 & 809,029 & 756,500 & $7 / 0,877$ & 744,201 \\
\hline DURBAN & $"$ & $1,84,5,403$ & $2,065,412$ & $2,029,322$ & $2,024,384$ & $2,021,826$ & $2,008,962$ \\
\hline PIETER MARITZZ- & , & 71,919 & 78,640 & $70,7 / 8$ & 70,924 & 69,473 & 66,936 \\
\hline BLOEMFONTEIN & $"$ & 114,725 & 141,499 & 146,211 & 159,459 & 166,556 & 157,135 \\
\hline TOTAL & \multirow{3}{*}{$\begin{array}{l}\text { FIRST } \\
\text { SECOND } \\
\text { THIRD }\end{array}$} & \multirow{3}{*}{$\begin{array}{r}7,524,785 \\
4,873,081 \\
6,380,832 \\
\end{array}$} & $7,882,176$ & $7,679,216$ & \multirow{3}{*}{$\begin{array}{l}, 255,329 \\
5,026,975 \\
7,247,963 \\
\end{array}$} & \multirow{2}{*}{$\begin{array}{l}6,722,729 \\
5,017,455\end{array}$} & \multirow{3}{*}{$\begin{array}{l}5,485,048 \\
4,903,100 \\
7,537,665\end{array}$} \\
\hline SURURRAN & & & $5,326,493$ & $5,156,523$ & & & \\
\hline SUBURBAN & & & $6,972,610$ & $7,021,389$ & & $7,553,912$ & \\
\hline AREAS & $\begin{array}{l}\text { GRAND } \\
\text { TOTAL }\end{array}$ & 18,79 & $20,181,579$ & $19,857,128$ & $19,530,267$ & $19,294,126$ & $17,925,813$ \\
\hline
\end{tabular}

This Table 1llustrates how passenger traffic was boing diverted to the road omnibus services - It mast be remembered, too, that the population of these areas was incresing over this pertod. In sppendix I a table is given to show the position on the Capetom-Iymberg route where the competition was most severe. These results are not unexpected because the demand for passenger sertice Is relatively elastic ocmpared with the demand for goods traffle. Bren where the rallwa fares were the same or less/.. 
less then the fare by'bus, the greater convenience and acoessibility of the 'bus sertices wes sufficlent to cause this ahange orer in demand. The line from Capetorm to Sea Point is a goad case in point. This line was electrifled at huge expense and provided a chep and frequent service but it was unable to meat the competition of 'buses which depasited and plaked up pessengers oloser to their homes. The omibus always possesses the big advantage of Nexibility. Bentualiy the Sea Point line was taken up.

As regards goods traffic, competition had not jet reached the atage where it was actually diminishing the total volume of high-rated traffic of the railways. This was the view of the Departmental Rallway Tariffs Inquiry Committee, 1930:-

"It is popularly supposed that the Administration hes already lost a large volume of high-rated traffle for short distances and that its position in this respect is already extremely precarious. It is, therefore, of interest to note that, although traffle is being conreyed by road, the rolume of high-rated traffic conveyed by rail for short distances has not diminished. On the contrary, it has Increased substantialig." I.

\section{TIBTE II.}

FTCRRASE IN HIGH-RATIA TRAPIIC, CLASSHS 1 - 6 , FROM 1925 - 1929.

\begin{tabular}{|c|c|c|}
\hline Tane & $\begin{array}{l}\text { Inorease for year ended } \\
\text { ended sigt Iarch, } 1925 \text {. }\end{array}$ & 31at Nareh, 1989 over year \\
\hline $\begin{array}{l}1-60 \text { miles } \\
51-100 \\
101-150 \\
151-200 \\
201-200 \\
251-500\end{array}$ & $\begin{array}{c}1 \text { rons } \\
157,313 \\
78,876 \\
11,567 \\
51,360 \\
31,627 \\
63,560\end{array}$ & $\begin{array}{c}\text { Parcentago } \\
23.1 \\
31.4 \\
28.2 \\
40.4 \\
37.1 \\
60.7\end{array}$ \\
\hline $\begin{array}{l}1-500 \\
501-500 \\
101-500\end{array}$ & $\begin{array}{r}425,72 \\
106,848 \\
70,564\end{array}$ & $\begin{array}{l}32.9 \\
38.7 \\
26.5\end{array}$ \\
\hline $\begin{array}{l}\text { II dietences } \\
-1800 \text { mfles }\end{array}$ & 756,817 & 35.2 \\
\hline
\end{tabular}


It is, of course, to be expected that this increase In tonnage should have taken place with the normal increase in trade and production during these ralatively prosperous years. It is however signiflcent that the percentage increase in goods carried at rates 1 - 6 was 35.2 \& (for all distances), whib the increase for rates 7 and Iawer was only 14.7\% orer the same period. The assumption can be made that the competition had not yet reachod rery threatening proportions. The objeat of the Dept. Committee in compiling these figares was to disprove the acousation that the rate policy of the Ldminiatration was destroying the high-rated traffio and that therefore there was no need for the Adminiatration to introduce panic rates. If this was true, then oqually there was no need for the panie, restrietive legislation that sabsequently passed to proteat the revenues of the ldministration.

The combittee foresan this objection, It would, howorer, be very unwse to deduce from the foregoing facts that the position of the Administration is not seriously threatened by soed motor competition. In our judgent the potential denger to the Bailway Administration through roed motor competition, is very grave indeed." 1 .

If then this potential denger is admitted, the fact Is inescepable that the danger came from the peouliarly disoriminating rating polloy of the South African Rallwass. The most rulnerable point of attack for road motor competition was of course the hleh-rated trafflc for short distances (the exeeptionally high teriffs are in part the reault of excesaive 'tapering') and, more particularly, the high-rated short distance traffle to branch lines because of the principle employed of 'splitting' branch 
Iine rates, 1.e. Instead of the mileage schedule rates applying for the throughout diatance, the rates are charged eeparately over the main and brench lines (e.8. the rate for conveying $100 \mathrm{Ib}$. at Class 1 over $150 \mathrm{miles}$ of main Ifne was $56 \mathrm{~d}$. as compared with $63 d$. for 100 miles of main - plus 50 iles branch line.l.

Lgain and again in reports of the General Lanager, In eridence given to the Road Motor Competition Commission, In statements in the Press, in debates in Parliament there appears the acousation that the"'motor lorry is taking the aream of the traffic". It is el ear that to ascertain the real reasons, which led to the pessing of the Motor Carrier Transportation Let, a careful examination mist be de of the tariff polfoy of the Administration. The finanolal success of the Railways had come to depend on a position where a relatively small volume of high-rated traffic contributed the major part of Its receipts from goods traffic. In a statement made by the Chairman of Boad Notor Competition Commission daring the taking of evidence, the preearious natare of the S.A.R.'s position was made olear:-

Tou heve this position, then, high-rated traffle carFied by rail amounts to about 2 million tons per annum and the rerenue earned is $20,250,000$; the Ior-rated traffic Is approximately 18 million tons and the revenue earned 27,250,000, wo that $12 \%$ of high-rated traffic produces $29,000,000$ in revenue, while $80 \%$ of the traffic (the 100rated percentagel only earns $27,250,000 . "$

The Boad Hotor Commission summed up the position as It in the Union at that date, 1989 -

Tite are setisfied from the evidence that there is serious competition in publio transport. The competition 1s, naturally, most intense in, and in the nelghbourhood of, the larger centres, but it is by no meens oonfined to suoh areas. There Is a distinet tendenoy for the competition 
to epread further afleld, the road competitors gradually extending the range of their operation .......

The competition assails mainly the higher-rated goods traffe and the short-distance passenger traffio of the S.A.R. 1 .

In subsequent chapters the changing nature of road competition will be indicated. When the Transport Board had brought the operators of transport agenoles under control, competition from traders and merohants using their own Iorries and from seren-seater taxis increased to suoh an extent that the dominlstration was again forced to seak legislative protection. Unfortunately for the General Manager of the Railways the $0 x$ - and donkey-ragons rere resurrected and the Administration 18 now clamouring for still more protection. 2.

1. Boad Wotor Competition Commission (1820 [U.G.8,1930]
p.10 parn. T4.

2. It wold be Interesting to have details of the comparative oharges of the tro forms of trensport, 1.e. of road and rall transport, but they are diffloult to obtain. In 1928 the raflway fare between Port Hizabeth and valmer was $20 /$ - for 60 tlokets, and wile the bus fare wes $4 /$ for 16 tlekets, the etving in time by road was nearly ten minutes. To instence the time saved by motor-transport - the railway in 1028 took 24 hours to ocmplete the distence of 72 miles betroen Battermonth and East London; the normal time taken by oar was 4 hours. 


\section{GHIFIRR 2.}

THE MEASURHS TAKEN TO MERT COMPETITION.

In the early stages some attempt was made by the Administration to win back traffic by the normal business prectice of improving the efficienoy of the Raliwajs. For Instance, to meet the competition for suburban pessenger trarfic in certain cases, suoh as the Capetorn suburbs, the train operation was eleotrified, more frequent services were introduced, new stations bullt and on the CapetownWynberg line cheaper fares were instituted in Apr1I, 1929. To regain goods traffic lost to the road, certain modifications in the rates were made and improrements effected in the colleotion, transport and delivery of geods. Complaints were received with greater attention and publicity cempaigns carried out.

The first legtalative step was taken when Railway Regulation No. 282 was promulgated. This regulation enforced Section 3 (b) of Act No. 22 of 1916. By this seation the Minister of Railways was empowered to differentlate in the charges for wharfage dues on goods coming in through harbours as between (a) goods imported by persons and flrms who contracted to have all their goods conveyed by rail between any points where, in the opinion of the Minister, there was competition between rail and ragon or other rehicle for the conveyance of such goods, and (b) goods imported by persons and firms who did hot so contract. 1.

The regulation was gazetted on June 27,1930 . It imposed supplementary wharfage dues of $1 /-$ per $1001 \mathrm{~b}$. on goods...

1. This set ras first introduced in the old Cape Parliament In 1908 to meet the situation that arose from ox-wagon competition. It was effectively u sed 22 years later to meet competition from a meohanical wagon. 
goods Imported into the herbours of the Union or South Vest Africa. The additional cherge was to be levied on those who did not make contracts with the cdministration. Over 7,000 such harfage contracts were signed and the mount collected in respeot of the supplementary dues up to the 31st March, 1831, was only 21,481 .

"Nthough the system of wharfage contracts is of Iimited scope, it hes, nevertheless, served a most useful purpose in cheoking the indisoriminate use of competitive road transport and in safeguarding rallway revenue during a perfod of finenclal distress." $I$.

Lnother coercive device adopted by the Railway Administration was 'The Tranaport Reciprocity Clause' in its tender forms. This olarse provided that suocessful tenders mast be prepared to have all their goods transported by the Administration's aervees - rail or road.

Considerable public opposition was aroused by these two measures and there is no doubt that they represent the rorst abuses of monopoly power, partioularly by a state department. They differ only in degree from the iniquitous system of secret rebates which was a common reature of the American Railroad Companies in the last quarter of the nineteenth century. 2 .

In 1929 the Government appointed the Road Motor Competition Commission to investigate and report on:

(I) the wole problem of roed motor competition and its bearing upon the road motor and the rallway servloes of the S.A.R. Administration having regard (a) to the fact that the main transport system of the/..

1. General Manager's Report for 1931 (U.G. 37,1931 ) p.20.

2. These measures vere only stop-gaps and designed to stay the rexpld rall in revenue whioh was so accentuated by the depression of 1929. 
the country is state-omed, in which rast sums of public money are invested, and (b) to the country's needs for its economlo development; and

(2) all the measures, if any, which should be adopted for the better regulation, co-ordination and control in the public interest.' (Terms of Reference.)

lany accusations were made by various public bodies that the Commission ras blased from the beginning and that it was guided solely by the interests of the Rallways. It was suggested that the terms of reference were such that the recormendations of the Commission were formulated without consideration of the evidence. The Report of the Commission was, however, not completely one-sided. It is true that the Commission seems to hare accepted quite uncritioally the stook arguments urged in most countries for the control and co-ordination of transport and the suppression of 'wasteful' competition. On the other hand it was admitted that competition of private operators had done a good deal to increase the effloieney of the Railway Administration. While granting that the Rallways suffered under cortain disabilities and that the competition was not 'falr' in its incidence (e.g. motor trensport did not contribute its proper share to the maintenance of the roads), the commission expressed itself as resolutely opposed to a state monopoly of trensport. The evidence against such a proposel is, however, overwhelmingly strong - in fact, almost unenimous.... Moreover we are satisfled that a measure of competion in public transport is healthy and desirable." I.

The Commission made the following recommendations, amongst others, to Parliement:-

(1) There ahould be no monopoly of public transport on roads, a measure of competition being acoepted as healthy and desirable.

(11) There should be rensonable control and regulation of 
public roed transport, and, for the purpose of exereising control, a regulatory body - a Roed Transportation Board - should be created with definite functions and powers. This body should be Independent in character, representative of diverse interests, and free from polftical control.

(1i1) 'Transportation areas' and 'transportation routes' should be preseribed by the regulatory body in and over whioh areas and routes it should exerolse control over all public road motor trensport. It is recognised that in many sparsely populated areas the need for suoh oontral may not yet exist.

(1v) No one should be permitted to engage in any form of public transport by roed in such areas and over such routes save under a 'public service 11 conoe'.....

(v) L'certificete of public oonvenience and necessity' and the compliance with conditions recommended in paragraphs 102 and 103 (provision of adequate third party insurence, compliance with published scele of fares and time-tables and with wage regulations, ete.) whould be made prerequisites to the grenting of a lleence to engage in any form of public transport in transportation areas or over transportation routes." 1 .

Wen the Motor Carrier Transportation Bill 'to provide for the control of certain forms of motor transportation and metters inoldental thereto' was introduced into the Hou ge of Assembly, the principle of control met with practically no opposition. The recommendation of the Commiseion rere, in general, accepted without mach alteration. The Opposition Party did indeed make a strong attempt to seaure/..

I. p. 54 para. $209(I)-(v)$. 
secure the full polfticel independence of the proposed Transportation Boerd. I

The Motor Carrier Transportation Act (No. 39 of 1930) was plaoed on the Statute Book on June 5, 1930, and came into foree on Januery $1,1931$.

By this Act a Contral Road Transportation Board with subsidiary local boards was established and emporered to Investigate any matter relating to motor ourrier trensportation in the Union and to submit recommendations thereon to the Minfater of Railways. In the original sat 'motor carrier transportation" was defined as follows:-

'Wotor carrier transportation' means transportation over any public road for reward (a) of any person by means of any motor vehiele (I) designed to carry more then eight persons including the eriver or (11) not designed exelusively for conveyance of persons and personal effects, (b) of eny goods by means of any motor vehicle designed wholly or partly for the carriage of goods lother than the personal effects of persons travelling thereonl.'

On the recommendation of the Board, the CovernorGeneral may, by proalemation in the Government cazette, define any area as a proclaimed transportation area and any publio road as a proclaimed transportation route. Once such areas and routes have been proclaimed any peraon destring to engage in the business of motor carrier transportation in such areas and over such routes mast apply for a motor/..

1. The recommendetion of the Commission regarding the removal of certain disabilitios on the Adminlstration ras adopted by the enectment of the Railways \& Harbours Regulation, Control and Management sct, 1916; Further Amendment Let 10. 40 or 1930. This empovers the Admintatration to engage in motor carrier transportation: provided that in respeet of vehicles used for carriage of goods by road within a municipal area other than to and from the railways, the Admin. shall be liable for the payment of any tax or licence moneys levied on similar vehieles by the local authority. 
a motor carrier certifloate to the Board or locel board; and emybody who operates without such certificate, or otherwise than in accordance with the provisions of the certificate, is guilty of an offence.

Iocal boards ere eppointed for every proclaimed area and for every proclaimed route other than a route falling wholly or partiy within more than one proclaimed area. The Iocal board exereises similar functions for its om area or route as are exeraised by the Central Board for the areas under its jurisdietion.

The main functions of the Board are (I)' to determine from time to time the volume and nature of motor carrier transportation wich shall be permitted to qerate over any proolaimed transportation route falling wholly or partly within more than one proolaimed transportation area;and (2) to reoeive and consider applications for motor cerrler certiflcates for motor carrier transportation over any such route and for the amendment of any such certificate previously issued and in its discretion to grant or reruse such applications wholly or in part, subjeot to the provisions of this lat." 1 .

It is provided in the sct that the motor carrier certificate lisued by the Board or local board shall spectify:(a) Person in whose favour It is 1ssued; (b) perlod of issue; (o) olass of motor carrler transportation in respect whereof It is Issued and were such trensportation relates to persons the class or classes of persons who may be conveyed under such certificates (d) the particular vehieles, Identified in such menner as may be presaribed by regulation, in respect whereof it may be issued; (e) the routes along wich or the area within wich the vehiales to which 
It refers may be used in motor arrier transportation.

Furthermore the Board or locel board is emporered to require the holder of any suab certificate (a) to operate any vehicle to which the certificate refers, solely between apeoifled places and according to a spocifiod time-table (b) to publish the acale of charges accepted by the Board or looal board upon the grant of his certifleate and adhere to such aharges for a reasoneble period of time and (c) to comply with such rurther conditions as may be prescribed by regulation.

In issuing certiflcates the Board and local boards are to be gulded by the following general 'prinolples'. Firstly when considering an application the Board shall publiah pertioulars of the applioation and afford a hearing to interested parties. The Board is to consider whether the applicant is likely to carry on under satisfactory oonditions regarding regularity of service, wages, ete; the transportation requirements of the public on the particular route and existing transportation faclities; the nature of transportation to which application relates and the reasonableness of the proposed charges; whether the transport to which application relates will adversely affect or assist any other transportation faclities and whether it can be co-ordinated with such facllities 'in manner whioh is economically sound and advantageous to the public; any other factors which in the opinion of the Board may affect the question whether it is desirable to grant such application; the viens of any affected local authority.

It is quite easy to see from the nature of these detailed instructions that the Board was intended to give the rullest proteotion to the Railways and this is borne out by the positive injunction in Section 13, Sub-section (3) -

Whenever any transport facilities in existence vithin any/.. 
any eree or over any route, are, in the opinion of the Board or local board concerned, satisfactory and suffioient to meet at a reasonable oharge the transport requirements of the public within the area or the route, the Board or local board shall not grant any certificate in respect of any motor carrier transportation within substantially the same area or over aubstantially the same route with such transportation facilities."

The period for which a certificate may be issued shall hot exceed 5 years; provision is mado for renewal and for the issue of tomporary certiflcates in conneotion with partioular events. Appeals from the local board to the Board are also provided for in the Aat.

The powers, they entrusted to the central and local boards are very far-reaching. They exeroise practically autooratio control orer motor carrier transportation and, as shall be shown below, they interpreted thelr instructions to imply the almost total suppression of competition between private transport operators and the Railwey Administration and between the operators themselres.

By Section 12 of the Act, horever, the boards were compelled to issue certificates to any person who, on January 1, 1931, was ocoupied in any motor oarrier transportation in any proclaimed area or route and oould satisfectorily prove that on Pebruary 28, 1930, he ras engaged on substantially the same transportation and afforded suoh transportation effictently and at a reasoneble charge. such certificates were made subjeot to review after 6 months and then might be amended or cancelled if the transport faeilities were in excess of public requirements.

Section 15 makes it 1 llegal for any person who has been issued a certificate to refuse, without suffielent reason, to convey any person or goods which he is authorlsed to oarry. Further it is 11 legal for him to depart from his 
published tariff of charges (if any) or to make a higher or to make a higher or lower charge then he ardinarily makes under similar eircumstances. Remuneration in kind is prohiblted. This is probably the most reluable seetion of the sot. It imposes something similar to the "common carrier" principle on the transport company and prevents the use of disoriminating monopely power betreen different purohasers.

It is the more valuable in that, as we shall see below, a large measure of local monopoly is granted to such companies. The Let provides for adequate security against loss of third parties and also lays dom that no member of the Railway Ldministration is to serve on the Board or local boards. This is an important principle for seouring impartiality of the boards' dealsions, but in practioe the Adminictration had no reed for representation to secure almost complete absolution from motor carrier competition.

In his report for the year ended 3lst March, 1931, the General Maneger of the S.A.R. noted that, noring to the adverse effect of the trade depression upon traffic returns it is not possible to give comparative statistios indicating the extent to which competition with the rallways has dimfnished during the year under review, but from general observations it can be stated that the railway rerenue has benefited considerably and will still further improve as the provisions of the sct come fully into effect." $I$.

It is pointed out that the pratection afforded for six months to those already engaged in transportation would lepse after July I, 1931, and that the 'present unrestricted competition in the proclaimed areas will then cease!. It mould, however, be a bed mistake to imagine that the ceneral Manager was satisfied - like oliver Twist he oried for more. vithin/..

1. (U.G. 37, 1937) p. aI. 
Within the terms of the original Act, the conveyance of any goods sold or being conveyed for sale by the seller, by a motor rehicle belonging to him, in the course of the delivery of those goods to their purcheser or to the place of sale or by a purchaser himself, did not constitute conreyance for reward. This report for 1931 atated that the exclusion of such transport from control had led to a rapid increase in the number of vehfcles owned privately by firms. Many people engaged in the business of motor carrier transportation evaded the Act by taking out trading licenoes so as to represent the goods carried as their ow property. The view of the General Manager was that "the transport of such goods (commodities of regular and quick sale) over long distances in the course of trede distribution is essentially the transport of public traffic ..... 'Hired' long-distance public road transport will eventually disappear and be supereeded by long-distance road transport operated by the treders and distributors themselves". 1. This Report also complained of the growing practice of using seren-seater taxis to operate regular services between defined points and thecoby eveding the necessity of taking out a certiflcate.

When the next Report of the Ceneral Manager ep peared, the reviow of certifiaztes issued under seotion 12 had been mede by the Board and the elimination of many services is reflected in this Report.

"During the year under review, railway revemue beneIited considerably, as a result of the action taken by the Road Transportation Board and subsidiary boards appointed nnder the Motor Carrier Transportation Act to ellminate road transport servioes in excess of public requirementa.", 2. The Report continued thet these benerits in the case of pessenger traffic were being increasingly nullified by the use of seven-seater taxt-cabs, especially in the Trenskeian 
territories, as omnibuses and, in the ouse of goods traffic, 'by the increasing ase by traders and industriallsts of their orm motor rehlales for the carriage of goods orer vide areas adequately served by rallway". $I$.

Under presaure from the Railway haminfstration and the Road Transportation Board, an amendment lat ras passed by the Covermment wich extended the scope of the definition of 'motor carrier transportation'. By the Motor Carrier Transportation Amendment Act, No. 31 of 1838, the derinftion was altered as follors:-

'Hotor carrier transportation' meens the conveyance of any person or any goods on eny public road by means of any motor vehfole, (1) for reward; or (11) in the course of any Industry, trede or business of waterer nature; or (1ii) by means of a motor rehiele the use whereor hes been obtained for reward, provided that

(a) conregence of farm products by their producer by means of a motor vehfele bolonging to him; and

(b) convejance by a farmer of his am farming requisites to the place where he intends using them, by means of any motar rehicle belongling to $\mathrm{hlm}$, and

(c) conteyence of not more than seren persons simultaneously, including the driver, and of personal effeots, and of any goods Intended for their orn use or consumption, by means of any wotor rehicle designed or intended for the conveyance of not more than seren persons, if guch rehiele is not used for resular conterance of persons for reward betreen partlouler pleces there reasonable faclilties are arallable for their converanoe orer the greater portion of the most practicable route betwean such pleces, by railuay or by means of any motor rehtale Isoued fith a motor oarrier certifiante. 
shell not be regarded as motor oarrier transpartation for purposes of this Lct." I.

The effeet of this was, of course, to bring the transportation by merchants, industrialists, etc. of their om goods within the control of the Road Transportation Board and to place some reatraint on the evasion of the law by the texis operating as omibuses. Framption from the obligation to take out a certificate mast, hovever, be granted (a) for conveyence of goods within any area defined by regulation (which may be determined differently for different classes of trensportation or for different localfties) by their seller for delivery to their purchaser, or by the purohaser or onner to the place where he intends to sell, use or store them, or by any persen to any place where he or some other person intends to exhibit them, by means of any motor vehicle belonging to the owner of suah goods or to the person conreying them; or

(b) for conveyance of goods by their omer from any place to the nearest rail ray station or town by means of any motor vehicle belonging solely to such ovmer.' Further, exemption to take out a certificate may be granted for the conveyance of goods in the area of jurisdiction of a olty council, town counall, eta. with a population of not more than 20,000 persons; or goods by any motor vehicle equired by local authority for reward within the erea of jurlsdietion of such body; or farm products from rarm to the nearest tom; or to parties of students, sporting teams, oto. If no reasonable facilities are provided/..

1. It may be mentloned that hospital ambulances and conreyance of any coffin or corpse for burlal' are also expresaly exompted from having to obtain a certificate. 
provided by the Rallways or elready certifled motor vehloles. 1.

Thus this mendment led to still further restrietion of road motor transport. The General Manager's Report for the year ended 3Ist March, 1933, noted a marked reduotion in road transport competition but oomplained that there was stfll a great deel of evesion of the lav by taxi operators. The difficulty was to prove to the satiafaction of the court that the taxi was maintaining a regular aervice between the defined points. In Natel 'hundreds of motor cars are being operated parallel to railway or road motor services'. 2. But even after all the hard work of the Transportation boards, the Ceneral Manager could still not find peace. From the dim past the spectre of the ox- and donkey-ragon had arisen, again to plague a harassed General Manager of Railways.

With regard to animal transport competition, oring to il nancial stringency and other hardships a large number of the poorar type of farmer has resorted to animal transport riding as means of livelihood. By reason of the extremely Iow rates charged by these operators, ..... the volume of traffic, mostly high-rated, filched from the rallways by these carriers has assumed considerable proportions." 2 .

The following Report reviewed the position brought about by Ieglslative action. "In the anmal reports for the last two years it was indicated that unoconomio competition Ith the Railways by road motor rahicle had been reduced to a minimum and that the position generally, in so far as road motor traneport throughout the oountry is concerned, has been placed on a much more aatiafactory besis." 3 .

$$
\text { at/.. }
$$

1. By this let Seotion 16 of original Act, which provided for adequate third party insurance, was repenied.

2. U.G. 34, 1933, p. 21.

3. U.G. 37, 1934, p. 27 . 
Lt the seme time the request for more effective control of texi operators, the re-enectment of seotion 16 of the original Act relating to compulsory insurance and some measure of control orer animal-drawn transport was repeated. By this time it is not surprising to find the General Manager contemplating the ldea of soclalism - all transport, road, rail, see and eir, should be pleced under a Minister of Transport and the main road services should be nationalised. The reasone put forward by the General Manager for the growth of animal-dram transport were: (1) exploitation of operators (2) out-throet competition amongst transportriders and (3) uneconomical transport charges. But feeling, perhaps, that the economic arguments vere not sufficlently strong, the General Monager, with delightful nalvete, essumed the mantle of the Soclety for the Protection of Gruelty to inimals. Transport ridere are accused of harsh treatment of theilitile grey donkeys' and pitiful stories of sufferIngs related. In fact the only reason not given is that some of the rates on the rallrays are so high as to permit the successful competition of the slow-moving, old-fashioned donkey-ragon. $I$.

The/..

1. Then certain transport companies in muniaipelities started to introduce trackless trams, the diffioulties of the Iacal boerds in authorising tempo rary departues from sohecuied routes by the bises during the change-over vere Iikely to prove so administratively great that a rurther amendment Act, lot Ho. 20 of 1934, was pasied. It authoIfed the Governor-Ceneral, on recommendation of the Board, to suepend 'wholly or partiy the operation of any provision of the lat, elther throughat the Union or in relation to any particular prociaimea transportation area or route'. This power was given for a year but was subsequently extonded for a further yoar and again until May 31, I937, duFing the last Parliamentary session though not without some demand for a complete review of the whole logislation. Th1s amendment Lot is an astounding instance of what Lord Hewart has called the 'now despotism' - It gires the Board, and through the Board the Minister of Railways, the porer to make regalations of the most far-reaching eharaoter whout any need to coneult or obtain Parliamentary approval. 
The extracts above that have been taken from the annual reports of the General Manager of the Administration are strong evidence thet, if protection of railway receipts are accepted as the criterla, the legislation has been most successful in achieving its object of eliminating 'rasteful competition' and the 'duplication of unnecessary aervices in excess of public needs'.

The reports issued by the Central Road Transportation Board provide the material from which it is possible to give some idea of the position of private road transport operators and of how far competition with the Administration hes been suppressed.

By Proclamation No. 210, I930 (published in Government Cazette of September 26, 1930) fourteen transport areas were proclaimed if th headquarters at Beaufort West, Bloemfontein, Capetown, Durban, Rast London, Johannesburg, Kimberley, Mossel Bay, Pletermaritzburg, Pietersberg, Port Hizabeth, Pretoria, Umtata and Zeerust.

The following public roads were defined as procleimed transportation routes:- 1 .

Between (1) /..

1. Since Jenuary 31, 1932, the following additional routes have been proolaimed. The public road between Capetown and Kimberley ria Durbanvilie, Tellington, Beinskloof, Ceres, Karroo Poort, Buikesfontein, kandsviei, The Bosch, Calvinia, Tilliston, Ldvance, Carnarton, Pampoenpoort, Victorla West, Hut chinson, Merwefontein, Richmond, Terborgenfontein, De Put, Britatom, Andraeieriel, Prieske, Niekerk's Hoop, Griquetom, Campbell and Sahmidt's Drift.

Public roed between Fest London and Bloemfontein Vla Stutterheim, Bolo, Great Kel Drift, Tsomo, Ingeobo, Coghlan, Mliot, Cala, Askeaton, Lady Frere, queenstown, Bailey, sterkstroom, Molteno, stormberg, steynsberg, Tenterstad, Bethulie, Orange Vlel, Bdenburg and Bethan

By Proclametion No. I34 of 1933 a transportation area for S.W. Africe comprising the magisterial districts of Gobabls, Karibib, Okahandja, Omaru and Windhook ras proclaimed, and a route defined betreen lialtahöhe and Windhoek via Marientel, Swartmodder, Hanover and Dordabus. Minor amendments of these proclamations have been made. Certain areas have been deproclaimed and the 'released districts dded to existing proolaimed areas or routes. These ajustments have bean made for adminfstrative parposes and not to reduce the areas under the control of the Board and the lacal boards. 
Between (1) Mossel Bay and Bequfort Viest;

(ii) Fast Iondon and Umtata;

(iiI) Durben and Johemnesburg;

(iv) Durben and Middelburg (Transvaal);

(v) Johannesburg and Louis Trichardt (via Pretoria);

(vi) Germiston and Pretoria (via Irene);

(vil) Zeerust and Pretoria (via Rustenburg);

(VIII) Zeerust and Johannesburg;

(Ix) Lichtenburg and Johannesburg.

By Proclamation No. 211 of 1930 all motor carrier transportation, as defined, after January 1, 1931, over these routes and areas is prohibited unless a motor carrier certifleate sanctioning such transport is issued.

The areas proclaimed included all the towns with a population exceeding 20,000, such as Capetown, Johannesburg, Durban, Bast London, Pietermeritzburg, Port Elizebeth, Klmberley, Bloemfontein, Pretoria, Springs, Brakpen, Benoni, Boksburg, Germiston, Krugersdorp, Roodepoort, Maraisburg and Randfontein, where the valume of passenger transportation in each, eccording to the Board, 'made it imperative that the control at which the legislatire aimed, should be exercised." I The proclaimed routes covered almost every mile of railway line in the country and on these routes the Board concluded that road transport should be subject to control, since it was found that many carriers of goods conducted frequent services...... and thet these carriers catered mainly for commodities classifled in the higher railway rates.'

Below a table is given to show the number of ordinary motor carrier certificates issued by the Board and the looal boards. The procedure which the Board followed in proclaiming an area or route was to visit the district and hold meetings at which the vlews of interested perties were heard/.:

1. First report of the Central Road Transportation Board (U.G. 2I, 1932) pp. 7 \& 8 . 
heard. But throughont the reports of the Board no definite principlea, on which decisions were besed as to whet constituted 'in exoess of publio requirements', are lald dom.

\section{PABTE V}

ORDINARY ANNUAL MOTOR CARRIER CERTIFICATES ISSUED BY BOARD AND IOGAI BOARDS. $\%$.

\begin{tabular}{|c|c|c|c|c|c|c|c|c|c|c|c|c|c|c|c|c|}
\hline DY & $\begin{array}{r}\text { PAS } \\
\text { VE }\end{array}$ & $\begin{array}{l}\text { SEN } \\
E H I C\end{array}$ & $\begin{array}{l}\text { IGER } \\
\text { CLEES }\end{array}$ & & DUA & $\begin{array}{l}A L-P( \\
V E H\end{array}$ & $\begin{array}{l}\text { URPO } \\
\text { ICLES }\end{array}$ & $\begin{array}{l}S E \\
5\end{array}$ & & $\begin{array}{l}600 \\
\text { VEHI }\end{array}$ & $\begin{array}{l}\text { ODS } \\
\text { ICLLE }\end{array}$ & & & Fit & Al & $S$ \\
\hline DF & 1931 & 1938 & 1933 & 18,34 & 193.3 & 1932 & 1933 & 1934 & 1931 & 1933 & 1933 & $1934 k$ & 9311 & 1932 & 1933 & 1934 \\
\hline RCaD Transportation BonRd & 39 & 34 & 29 & 30 & 66 & 282 & 372 & 399 & 179 & 291 & 228 & 279 & 284 & 607 & 629 & 708 \\
\hline LOCAL BOARDS:-BEALFORT WEST & - & - & - & - & 9 & - & - & - & 11 & - & - & - & 20 & - & - & - \\
\hline BLOEMFONTEIN & 29 & 35 & 11 & 14 & 27 & 27 & 13 & II & 76 & 66 & 29 & 42 & 132 & 128 & 53 & 67 \\
\hline C.APETONN & 279 & 248 & 240 & 208 & 42 & 100 & 276 & 388 & 642 & 619 & 498 & $572 \mid=$ & 793 & 967 & 1014 & 1168 \\
\hline DURGAN & 173 & 145 & $1 / 38$ & 145 & 37 & 9 . & 6 & 5 & 384 & 336 & 336 & 390 & $594 \mid$. & 490 & 480 & 540 \\
\hline EAST LONDON & 27 & 23 & 20 & 19 & 34 & 34 & 41 & 43 & 57 & 52 & 71 & 79 & $/ 18$ & 109 & 132 & 141 \\
\hline Johannesburg & 251 & 250 & 264 & 280 & 98 & 3 & - & - & 376 & 414 & 532 & 1092 & 725 & 667 & $r 96$ & 1372 \\
\hline KIMBERLEY & 1 & 3 & 4 & 3 & 43 & 22 & 43 & 38 & 68 & 24 & 13 & 10 & 105 & 49 & 60 & 51 \\
\hline$X$ MOSSEL BaY & 4 & - & - & - & 18 & - & - & - & 12 & - & - & - & 34 & - & - & - \\
\hline PietermaritzBur & 4 & 9 & 12 & 24 & 2 & - & - &.- & 29 & 32 & 29 & 31 & 35 & 41 & 41 & 55 \\
\hline$x_{\text {PIETERS BERG }}$ & 7 & - & - & - & 25 & & - & - & 22 & - & $\cdots$ & - & 54 & - & - & \\
\hline PORT ELIZ ABE TH & 98 & 82 & 72 & 84 & 3 & - & - & - & 209 & 100 & 135 & 155 & 310 & 182 & 210 & 239 \\
\hline PRETORIA & 71 & 81 & 45 & 59 & 16 & 53 & 63 & 21 & 85 & 104 & 80 & 106 & 72 & 240 & $/ 8 \delta$ & 186 \\
\hline$x_{\text {Utata }}$ & 8 & - & - & - & 26 & - & - & - & 32 & $-\cdots$ & - & - & $\mid 66$ & - & - & - \\
\hline$x^{x}$ ZEERUST & 10 & - & - & - & 2 & - & - & - & 16 & - & - & - & 28 & - & & - \\
\hline${ }^{\circ}$ WINDHOEK & - & - & 1 & 1 & - & $\cdots$ & 35 & 47 & - & - & 2 & 1 & - & - & 38 & 49 \\
\hline TOTALS & 11001 & 910 & 836 & 867 & 448 & 530 & 849 & 9952 & 222 & 2040 & 91956 & 62757 & 3620 & 3480 & 3641 & 469 \\
\hline
\end{tabular}

I Deproalaimed in Ootober, 1931 and included in other areas or bought under proclaimed routes.

- Proclaimed in 1934 and brought under Aot.

These Hgures thow a decline in the number of certiflcates issued for passenger and goods vehicles from 1931 to

1. In Viatoria, Australia, in the lot of 1933 it was proTided that if the Board refrsed to grent Ilcenoe to the epplioant, it could be roquired to give in witing its reasons for rerusal. These mitten recislons' constituted the ohter souroes of the prineiples of the Board. This legal provision is an Important point in adminlstrative jurisdiction as it tends to secure that the body concerned WII be ided by a definite set of recorded deolsions. This provision ras later repealed.

8. Compiled from amual reports of Central Road Transportation Boerd. 
1933 and then a change uprards for 1934, especially in the case of goods vehieles. The number of dual-purpose rahicles increased steedily throughaut the period but such rehioles ueualiy have a relatively small carrying capacity both of pessengers and goods. These statisties do not show the full measure of reatriation imposed by the controlling authorities.

In the first place it is Iikely that many carriers who sad operated services did not bother to apply for certificates to the Board or local board in the belief that suab applications would be refused. It seems that there was quite widespread feoling amongat small operators that the Board was, in fact, merely a tool of the Rallway Adminiatration. This supposition is borne out by a statement in the Beport of the Central Board for the year ended 3lst March, 1934. "It is also a fact that a considerable number of carriers who had,prior to the passing of the Act,operated apesmodio services over these and other routes never applied for certificates, realising no doubt that the nature of their services ruled out any question of proteotion. An Instance of this was seen on the Transkel route where, pisior to Jenuary lst, 1931, there were over 60 vehieles operating betreen Bast London and the Transkel, while the applications for motor carrier certificates in respeot of that route related to less than a third of that number." 1 . In his Report for 1931 the General Manager of the S.L.R. also noted that the grouth of competition had been arrested in pert by anticipated erfeots of the Let. $\Delta I 1$ this implies that the number of operators before the Act came into force was greater than the initial number of certifioates iasued under seation 12 of the Aat indicates. It implies, further, that/.. 
that many operators who were operating apparently on a profitable basis and others who oonsidered that the motor cerrier business offered a profitable fleld for investment were diverted from it into other less profitable ventures.

Furthermore when certificates were issued, the conditions of issue often, in fact, resulted in a large measure af protection being afforded to the Railway Administration. In many cases the frequency of operetion was reduced, in other cases the actual length of service permitted ras curtailed, 1.e. the service was only allored to function over a portion of the former route. Many certificates, too, were issued to operetors whose services were diverted into the so-called oo-ordinated services. Another device used by the Transportation Board to suppress competition without reduoing the actual number of vehicles was to enforce a certain soale of fares or rates on the operator. The tariff was so fixed as to eliminate the 'undercutting of railwey rates classified in the higher classes'.

By Section 12 of the Act, it will be remembered, the Board was compelled to issue certificates to oarriers who, prior to Pebruary 28, 1930, had operated regular services. After June 30, 1931, the Board had pover to revien such certificates and reduce their number, if so desired. Unfortunately no clear statistical statement was given by the Board of the position after the review. It would be too tedious to reproduce the whole oomplicated statement of the Board of the review but certain instances abstracted from its first report will indicate the drastic manner in which the revier was carried out.

On the East London-Umtate route 5 carriers had been issued with 8 aertificates for through goods services. On revier the number of vehioles was reduced to 4 and the frequency of $z$ services from two trips per week to one. When 
renerals for this route were considered for 1932, the Board declded that there was no necessity for through road transport between the points specified and the applications were refused.

Under section 12, 9 certificates had been issued for the Durban-Pletermarltzburg route in terms of which daily services were operated in respect of all classes of goods. on review the Board cancelled all the cortificates but carriers were authorised to convey fumiture and household effeats. In Januery, 1934, applications relating to the conveyance of all classes of goods rere refused.

On the Johannesburg-Pretoria route applications from 20 operators had been granted under the relevant seotion. Sixty oertificates were issued - 44 for goods of all olasses, 16 for furniture and household effects only. As a result of the revien all carriers engaged in the trensport of furniture were granted certificetes but only 5 certificates for goods, all classes, were issued. When applications for renewal were considered for 1932 all applications for conveyence of goods, all classes, were refused but the removal of furniture ras again authorised.

On the same route a passenger company was granted 6 certificates. At the revier stage the Board authorised the continuance of the service but ordered alteration of the time-tables, prohibiting the running of 'buses in close proximity to the times of departure of fast trains between Johennesburg and Pretoria.

Locel boards carried out a simllar process of eliminating 'vasteful competition' and bringing about a 'stable, vell-belanced syatem of transport'

The position the beginning of 1932 was as follows:"At the review stage which covered the period July to October, I931, this competition was considerably reduced, and when applioations for renewals of certificates rere made to the 
Board and local boards during December, 1931, and January, 1932, competition was further reduced. The process hes been continued in respeat of applications for certificates for the current year and further ourtailments of services have been effected in those cases where it was found that an unnecessary duplicetion of service existed.

Wut it would not be correct to say that all wasteful competition had been eliminated and that a condition of stability has been reached. Adjustments will from time to time become necessery; the principle of co-ardination will have to be applied further in cortain ceses and the elimin tion af those competitive services which cannot usefully be co-ordinated All have to be considered. The majority of those 'original' operators have, however, been restrioted to areas or routes where they ere employed in affording useful services." I.

From the beginning of 1932 the Board began to 'co-ord1nate'. 'Co-ordination', maglc word, apparently meant that if a road service oould be so diverted as to act as a fooder to the services of the Administration, then the service was co-ordingted; if not, then the service beceme 'unnecessary duplication' and 'In exoess of public needs' and hence eliminated.

The Report of the Board for 1934 stated that in the case of operators whose competitive services were discontinued, they were 'werever possible diverted into spheres were a much noeded service could be rendered by co-ordinating their transport operations with the ldministration's rail or road motor services or with other previously existing private services....... In most osses the carriers whose services were so co-ordinated are today engaged in supplementing the ra11/..

I.

Report by the Transporation Board for year ended 31 st Maroh, I933 (U.G. 20, 1933) p. 8 . 
rail gertice by means of feeder lines radiating from railhead into areas not served by rail." 1 .

For the year Jenuary, 1932, to December, 1932, the looal board at Capetom granted $\mathbf{9 6 7}$ applieations out of 1120 and the number of passenger 'buses operating in the area was reduced from 279 in 1931 to 167 in 1932 . In regard to goods transportation, the local board has adopted the principle of co-ordinating rail and road transport and has by this means considerably reduced the excess of facilities arer requirements of the publio'. 2 . In 1831 authority to operete was sought for 672 lorries for through transport between Gapetown and outIying dietriets as far afield as Calvinia, Sutherland, Worcester and Bredasdorp. During 1932 only 67 applications ware made to the board, due in the board's opinion to the fect that "operators had become acoustomed to and had accepted the system of co-ordinated transport wich had been introduced." 2 .

The effect of the orfginal Lot was, as stated above, to lead to a sharp inoresse in the use of seven-seater taxis as omalbases and in the use by merchants, traders, industrialists, ato. of their own transport.

"In certain perts of Natal the position has become so acute that it is no exaggeration to say that a condition of ohaos exists. In a report submitted to the Board recently, it was stated that there were literally hundreds of motor cars, flve- and seven-seaters, so old and dilapldated that ane wonders how they were ever pessed by the rehiele inspectors, on the roed carrying natives from Durben to all parts of Natal and zululand. Hundreds of these exrs had actually been seen to leave with anything up to 9 or 10 natires/..

I. U.G. 30, 1934, pp. 9, 10 .

Z. U.G. 20, I933, p. 24. 
natives in each and in addition carried goods of all descriptions on the running boards." $I$.

"It has come to the notice of the Board that in recent months hundreds of motor vehicles have been acquired by merchents and are being operated from inland centres to and from the cosst." 2 .

Competition, like murder, will out!

By the mendment Lot 'vehicles operated by merchents, manufacturers, industrialists, traders, bullding contractors and by all other concerns in the course of their commercial and Industrial activities' are subject to the provisions of control. At the same time, the Board ras compelled to grent exemption from the obligation to take out a certificate In respeat of the conreyance of goods in the course of a business, trade, or Industry within areas to be defined by regulation.

It thus became necessary to define such areas. The Board proposed that in general the normal area of exemption should be the magisterial district, bat in the case of a fer centres the Board suggested that larger areas, comprising two or more magiaterial districts, should be defined. sfter consultation of various interests and visits to the larger centres, the Board issued Motor Carrier Regulations (Covt. Notice No. 1028, dated August IO, 1932) and the normal exempted areas were defined with minor alteretions as suggested by the Board.

Special provision was made in the regulations for wider exemption in respect of the oonveyence of nerspapers, builders' plant and soaffolding and commeroial travellers' samples; a general provision was made for the grant of

1. U.G. 21, 1938, p. 24.

2. U.G. 2I, I832, P. 25 . 
vider exemption 1f, in the opinion of the Board or local board, any goods must necessarily be conveyed by motor vehiole.

Applications of those who required exemption within the defined area were, of course, automatically granted. In certain cases the Board granted exemptions beyond the normal defined area, e.g. (I) conveyance of assembled radio sets, electric stoves and electric refrigerators, (2) conveyance of tools and spare perts in oonnection fith the installation, maintenance and repair of agricultural or industrial plant, (3) conveyance of boring apparatus, (4) conveyance of roadmaking materials (tar and bitumen) in specially constructed spraying tanks. 1 .

\section{TABLE TVI}

NUMBER OF LXEMPTIONS ISSUED 1932 - 34. 2 .

\begin{tabular}{|c|c|c|c|c|c|c|c|c|c|c|c|c|c|c|c|}
\hline & 1932 & 1933 & 1934 & 1932 & 1933 & 1934 & 1932 & 1933 & 1934 & 1932 & 1933 & 1934 & 1932 & 1933 & 1934 \\
\hline & \multicolumn{3}{|c|}{$\begin{array}{l}\text { CENTRAL POAO } \\
\text { TRANS. BOARD }\end{array}$} & \multicolumn{3}{|c|}{$\begin{array}{l}\text { BLOEMFONTEIN } \\
\text { BOARD }\end{array}$} & \multicolumn{3}{|c|}{$\begin{array}{c}\text { CAPETOINN } \\
\text { BOARD }\end{array}$} & \multicolumn{3}{|c|}{$\begin{array}{l}\text { DURBAN } \\
\text { BOARD }\end{array}$} & \multicolumn{3}{|c|}{$\begin{array}{c}\text { EAST LONDON } \\
\text { BOARD }\end{array}$} \\
\hline No. of ${ }_{\text {appations }}$ & 1487 & 2463 & 2760 & 96 & 212 & 155 & 1525 & 1605 & 1963 & 536 & 765 & 790 & 343 & 444 & 406 \\
\hline $\begin{array}{c}\text { Vehicles } \\
\text { Involved }\end{array}$ & 2498 & 3875 & 4352 & 119 & 245 & 196 & 2161 & 2173 & 2608 & 798 & 1053 & 1100 & 398 & 408 & 504 \\
\hline \multirow[t]{2}{*}{$\begin{array}{l}\text { Vehicles } \\
\text { Exempled }\end{array}$} & 2445 & 3840 & 4325 & 109 & 234 & 191 & 1926 & 2151 & 2598 & 792 & 1040 & 1095 & 389 & 407 & 488 \\
\hline & \multicolumn{3}{|c|}{$\begin{array}{c}\text { JOHANNESBURG } \\
\text { BOARD }\end{array}$} & \multicolumn{3}{|c|}{$\begin{array}{c}\text { KIMBERLEY } \\
\text { BOARD }\end{array}$} & \multicolumn{3}{|c|}{$\begin{array}{l}\text { PIETERMARITZBURG } \\
\text { BOARD }\end{array}$} & \multicolumn{3}{|c|}{$\begin{array}{c}\text { PORT ELIZABETH } \\
\text { BOARD }\end{array}$} & \multicolumn{3}{|c|}{$\begin{array}{c}\text { PRETOR/A } \\
\text { BOARD }\end{array}$} \\
\hline $\begin{array}{l}\text { No. of } \\
\text { applications }\end{array}$ & 498 & 1531 & 2224 & 125 & 166 & 219 & 126 & 146 & 119 & 230 & 389 & 464 & 313 & 494 & $5 f 8$ \\
\hline $\begin{array}{c}\text { Vehicles } \\
\text { Involved }\end{array}$ & 1345 & 2230 & 3087 & 149 & 187 & 238 & 159 & 174 & 149 & 252 & 471 & 582 & 454 & 603 & 662 \\
\hline \multirow[t]{2}{*}{$\begin{array}{c}\text { Kehicles } \\
\text { Exempled }\end{array}$} & 1277 & 2213 & 3045 & 144 & 187 & $2 / 7$ & 129 & 174 & 149 & 234 & 4601 & 561 & 395 & 588 & 655 \\
\hline & \multicolumn{3}{|c|}{$\begin{array}{l}\text { WINOHOEK } \\
\text { BOARD }\end{array}$} & & & & & & & & & & \multicolumn{3}{|c|}{ GRAND TOTAL } \\
\hline $\begin{array}{l}\text { No. of } \\
\text { applications }\end{array}$ & - & 62 & 63 & & & & & & & & & & 5579 & 8227 & 9751 \\
\hline $\begin{array}{c}\text { Vehicles } \\
\text { Involved }\end{array}$ & - & 62 & 63 & & & & & & & & & & 8333 & 11,556 & 13,541 \\
\hline $\begin{array}{l}\text { Vehicles } \\
\text { Excmpted }\end{array}$ & - & 58 & 63 & & & & & & & & & & 7840 & 11,425 & 13,387 \\
\hline
\end{tabular}

1. Some of the fectors considered by the Board when deciding applications for wider exemption are (as glven in its second report $1:-$

(at need for personal supervision of goods in transit;

(b) contractual condition of installation by the omers' mochanics or engineers;

(c) the inherent properties of certain goods, which require conveyance in specially constructed equipment.

2. Compiled from annual reports of Central Road Transportation Boerd. 
These figures of exemptions grented include those exemptions granted to farmers conveying their own produce from farm to nearest station or village or from station or village to farm. The figures, however, refer in the main to exemptions granted to merohants, traders, manufacturers, atc. and the rise in the number granted refleots the increased use of their om road trensport with the revival in trade. It mast be remembered that within the exempted area, the Board or local board compelled to grant exemption.

In the report of the Central Board for year ended 3lst March, 1934, statistical tables are given of the annual motor orrier certificates lssued and the following conclusion arrived et:-

"These statements indicate that while the aggregate number of certifloated vehicles fluctuates from year to year there has been no sherp diminution and support the Board's contention that the number of vehicles for which certificates have been refused is relatively small and that most of the original carriers are still operating today." 1 .

This gives the impression that the Board has granted only a moderate amount of protection to the Railway and that there till remains a large measure of competition In the transportation industry. Comment has been made above on the figures but it will emphesise the preatical monopoly acquired by the S.A.R. Administration. if the methods of suppressing road motor competition are stated again.

Even in those cases where certificates have been issued, this does not mean that operators were allowed to continue their businesses as they had done previous to the Institution of the Transportation Board. In the majority of instances their services were diverted and co-ordinated with the Administration's services; in some instances operators/.. 
tors have been reatricted to only a portion of their former route; the frequency of the service has been curtailed (an example has been given above where 'buses were prahibited from operating at the same tim as the fast trains) and minimum cherges fixed. The control of motor-vehicles operated by merohants in the conveyance of their own goods was, as the Board Itself admitted, 'a far-reaching departure from the existing provisions of the original Act'.

If the Increase in the number of exemptions issued over the period of three years is indicative of a growing preference by merchants for road transport, then it is reasonable to expect that far from a 'sharp diminution' there would have been a sharp increase in the number of annual certificates issued. It is certain that during the recent revival in trade, if there had been no controlling authority there would indeed have been great activity in the motor carrier transportation industry and the raot that the number of certificates issued to operators has remained fairly stable is in itself strong evidence of the elimination of competition.

At the present time the Administration has still to contend with the competition of the seren-seater taxis and of animal-drawn transport. The Administration, with the concurrence of the Transportation Board, is pressing strongly for wider powers of control over both these forms of competitiva transport. 
RATITAY MANAGBMENT \& RAIITAY RATRS IN SOUTH AFRICA.

In South Africa with its long distances, sparse population and bad roads it is obvious that the competition of road motor transport could not have seriously affeoted the Railways and that any effect it might have had ras due to a retes structure, which bore little relation even to the accepted prinoiples of public utility charging. There is abundant evidence that the fundamentel reason for introducing the restrictive legislation was, in fact, to proteet the rating policy of the S.A.R.

The Departmental Kallway Iarffrs Inquiry Committee, 1930, wote:

"We thus arrive at the conclusion that, if road motor competition is allowed free rein, it can decide the main feature of the rates policy of the S.A.R. and, what is much worse, can force the Administration to carry out a rates policy which is direatly contrary to the general interests of South Africa, and also contrary to the injunotions of Seation 127 of the S.A. Lat. Te attach great importance to this point and would direot special attention to it as It appears to constitute a very strong argument in favour of the proposed legislation." 1 .

In introduoing the bill to provide for the control of road motor transport, the Minister of Railways advanced three reasons for the desirability of control, one of which was:- "Our whole rate system is bullt upon a basis that highly-paying traffle must pay a high rate and low-paying traffic, like agricultural produce and base metals, should 
pay a low rate." I. 1.e. the reason was to proteat a part1cular rates structure.

It thus beoomes necessary to examine the management and rating polloy of the S.A.R. at that period (about 1928-1930). In an ertiole entitled Rallway Rates and Road Competition In South Africa", the author bluntly stated, Moreover, Parliamentary control has distorted rate polioy and reduced operating effloiency to such an extent that the railways lack the capcity of privately run enterprise to meet the competition that has arisen. The traffic has changed in nature and direotion, and the changes in the degree of disoriminetion in fates between different classes of goods and different lengths of fourney have not met the new conditions. Competition has increased, and at the same time the railway's capacity to withstand it has been reduced by political policies which have contributed nothing to efficiency of operation." 2 .

When one wishes to investigate rallway management in this country, one turns naturally to Professor Frankel's book, 'The Railway Policy of South Africa since Union'. The following information is taken mainly from this work. 3.

When the provisions relating to the S.A.R. in the South Africa Act vere drawn up, it seems fairly certain that the framers of the let intended to devise a form of managerial control, similar to that which had so successfully operated in the case of the Central South African Railways, which would arold the possibility of politioal interferenoe in what was to be essentially a business undertaking.

From the outset, howerer, the Railways and Herbours Board, which was to exeroise 'subject to the authority of the/..

1. Hon. C. W. Malen col. 3671 House of Assembly Debates,1930.

2. Round Table No. 77, 1929, p. 185.

3. It must be noted that I am not here concerned if conditions have ohanged for the better or worse at the present day; I am concerned with conditions relevent to thet period 1928 1830. 
the Governor-General-in-Council, the control and management of the railways, ports and harbours of the Union', was regarded as a purely adisory body to the Minister of Railways. All real pover was withdram from the Board and this apparently wilful miainterpretation of the South Africa Act was given legal effect in the Amendment Act of 1916 . This Aot stated that ' the working and management of the Railways and Harbours shall, subjeot to the control of the Minister, be carried out by the General Manager, who shall be governed by such regulations as the Minister may from time to time frame after consultation with the Board.' Thus the railways, from the very beginning, were subjeat to that political interference and pressure, which has always been the atrongest argument against state intervention.

Seotion 127 of the S.A. Act laid down that, "The railways, ports and harbours of the Union shall be administered on business principles due regerd being had to agricultural and Industrial development within the Union....". The whole tone of the relerant clauses is such as to leave little doubt that the emphasis ras placed on 'business prinoiples'. Note, for instance, the safeguards provided against the building of branch lines so as to win political ferour. The Board was charged with the investigation of every proposal for the construction of any new line and if Parliament should over-rule the negative decision of the Board, then the annuel loss on the line as estimated by the Board was to be met from the Consolidated Revenue Fund. By Section 13I of the Act, If the Board is required by Parliament ' to provide any serviees or facilities aither gratuitously or at a rate of charge which is insufficient to meet the costs involved in the provision of such services.... the loss incurred shall be paid out of the Consolidated Revenue Find to the Rallways and Harbours Fund'.

This Act also prescribed the general lines of the rating policy/.. 
poliey to be pursued - 'So far as may be the total earnings shall not be more than are sufficient to meet the necessary outlays for working, maittenance, betterment, depreciation and the payment of interest due on apital, not being capital contributed out of rail way and harbour revenue'.

How far have successive Union Governments fulfilled the spirit, if they have the letter, of these provisions?

The figure of $286,352,960$ adopted as the amount of capital, on which interest was to be paid to the general revenue, was purely an arbitrery one and represents - according to the late Prof. Lehfeldt - an overstatement of approximately 213 millions. This means that an excess payment of nearly $\$ 459,000$ p.a. has been mede to general revenue. (Changes in the purchasing power of money are apparently neglected.)

oring to the fact that no definfte scale of depreciation was decided upon, the Renewals Fund has been used for purposes other than for those for which it was constituted. During the years 1912 - 1927, the total gross expenditure on new rolling stock met by a charge against the Renewals Fund amounted to $214,507,343$ as compered with $21,670,227$ value of rolling stook actually withdram from service. "Under this system the railways continued to pay depreciation on rolling stock that pad already paid for itself." I. The unnecessarily high and illegitimate contributions made to this fund have placed a burden on the present users of the railways conservatively estinated by Frankel at between half and three-quarters of a million pounds per annum.

The use of monies from the Renewals Fund appears to have been chiefly due to the difficulties of the General Manager in obtaining even the most essential capital funds for new rolling stocks. The failure to provide for such vital/.. 
Vital capital expenditure meintained operating costs at a relatively high level and thereby curtailed the development of trafic.

Prof. Frankel wites, The Union Government has aggravated the curtailment of necessary capital expenditure by influencing in an inexcusable degree the direction in which the capital expenditure for railway purposes were to be spent". 1. This is the notorlous problem of political intervention in the construation of branch lines.

After an exhaustive examination of the working results of such branch lines, Frankel concluded: "One is forced to the conolusion that either the methods of estimation used by the Board are grossly and inexcusably inefficient, or that the estimates are deliberately so framed as to make it possible for the Board to sanetion the building of lines at the expense of the Railrays, the construction of which it would otherwise have to oppose strongly in accordance with the provisions of the S.A. Act, and which could then only be constructed at the expense of the Consolidated Revenue Fund." 2. Railways have, in fact, been built in areas suffering from periodic drought and with declining populations.

"In 1926 out of 70 brench lines, only 10 showed a net profit, 32 peid working expenses but were unable to meet full interest payments, while 28 showed earnings which were not even able to cover working expenses. The total losses on these lines, after the payment of interest, amounted to 2526,596." 3. An excellent illustration is the Toums River-Ladismith line - it was opened in November, 1925, a Ine of 88 miles; the Board's estimate of revenue for the first/..

1. Synopsis of Conclusions, p.14 Gonclusion No. 31 .

2. p.15, Conclusion No. 36 .

3. Ch. II, p. I20, pare. 83. 
first year of working was 225,088 while the actual revenue in 1926 was 26,056; The Board's estimated surplus of revenue over gross working expenditure (including interest charges) for the first year of working was 28,984 while the actual shortfall of revenue was $27,095.1$.

It must not be overlooked that apart from the direct loss on branch line constmuction, there was the even more serious indirect loss from the curtailment of necessery capital expenditure in other directions.

The co-called civilised labour pollcy placed a burden on the railways of at least $\$ 300,000 \mathrm{p} . \mathrm{a}$. and probably very much more. This extra labour cost should have been borne by the general revenue. Other examples of gratuitous servioes for which the cost should have, but had not, been paid over to the Railways and Harbours frund are the conveyance of drought-stricken animals ( 2150,000 p.a.), free passes to members of Parliament and the granting of annual halfprice concession fares to over 26,000 civ1l servants and their families. Without questioning the merits of these services, legally the cost should not have been a charge on the railway users.

Prof. Frenkel has estimated the total direct burden at 22, 200,000 p.a. This burden does not, of course, fall on all the trafic but only on the high-rated traffic and relief from these burdens would have enabled a reduction to have been made of $22 \%$ on the tariffs of goods classed in the high-rate schedules. It is hardly necessary to point out that this in turn would lead to an extension of demand making possible further decreases in the rates.

The General Manager himself admitted that improvements in the transit and handing of goods traffic had reoaptured some of the traffle Iost to the road. If at the same time a reduction of over $20 \%$ had been effected on the higher-rated traffc through the strict enforeement of the law, the Railway Administration/.. 
Administration would most likely have been able to meet the competition of road motor transport without the need of legislative aid. According to the General Manager in his report for 1933, the average cost of road transport for long-distance traffic is at least four times as high as railway transport and this brings out clearly that road transport is not more economical than rail transport. He stated that the real fact at issue was that the effects of road competition would be that 'the railway tariff polioy of the country would be disrupted with disastrous effects on the farming, manufacturing and mining industries of the country', 1 .

But if the rates had been reduced by $20 \%$ on the traffic for whioh there wes competition, through the administration of the railweys on strictly 'business princlples', competition of the road motor would hardly have been disruptive of the established rating system. This factor will be taken up again below.

The real value of a road motor carrier industry developing in competition with an already existing railway system is that it goes far to solve the very difficult problem of rallway rating. Any text-book tells us that the method of charging in railway transportation is necessarily a differential one, or in other words that the railways are a striking example of a discriminating monopolistio enterprise. The function of State ownership of the railways is to prevent the abuse of monopolistic power that would be avallable to a private oompany. On almost every railway system in the world the state has found it necessary to impose some Iimitation on private operation in order to safeguard the railway users from monopolistic exploitation. In South Africa, on the other hand, the effeat of state interrention has been to make the railway tariff an instrument not only of 'simple' differential charging but for giving a concealed subsidy to one particular 
industry.

Prof. Frankel puts the faots squarely,

"Certain classes of traffic are charged as mich as the railways can possibly extort, regardless of whether the resulting rates restrict trafic which would be offering were the rate reasoneble; at times the Railway Administration appears actually to ain at restricting various kinds of trafflo; other large traffic are charged at rates disproportionately below that which, in accordance with their nature and value, and the cost involved in transporting them, they should be required to bear.

While the Administration apparently aims at stimulating South African exports, and grants a bounty on agricultural exports, its policy with regard to the greatest export industry of the country - the gold mining industry - is the opposite; and the Administation has for years aeen fit to restrict the activities of thispital industry by glaring discrimination In the rates on the stores consumed by it." 1 .

It is easy then to understand, in view of the above, that the State did not look with favour on the motor lor ry as the solution of the problem of monopoly charging on its railways.

\section{Brief history of railway rates in South Africa:-}

Prior to Union the coastal colonies of Cape Province and Natal did their best to exploit the position of the inland territories to the umost. A further factor in the system of charging at that period was that trucks going up fully loaded to the Free State and the Transvaal, returned preatically empty to the coast. Thus the goods to the gold and diamond mines had to bear a rate which would oover the costs of rorking involved in both directions. Natal and the Cape Provinoe used their railways in conjunction with customs duties/.. 
duties to fill their treasuries. It has been stated above that by the South Africe Act the railways were not intended to make a profit, but many of the features of pre-Union rating policy still remain. For instance, even today an at tempt is made to arrange for an 'oquitable' division of the traffic between the various S.A. ports and Delagoa Bay. "If one sought the key-note of railway rate polloy in the four territories which now comprise the Union, it would probably be found in the idea of fixing rates for development purposes rather than with the object of performing the greatest possible immediate service to the community." 1.

The system of preferential rates on S.A. produce and manufactures originated in pre-Union days when these rates were used to cepture the Transvarl market. The system was condemned as far back as 1898 by a Cape Select Committee and by the Inter-Colonial Railway Conference at Pietermaritzburg in 1906. In 1911 at Union, the General Manager of the S.A.R. said, The prinoiple of preferential rates for S.A. articles is one which should, in my opinion, be entirely abolished". The policy was howerer continued and even extended during the Far and the slump of 1921.

A preferential rate was defined by the General Manager of the Natal Government Railways as follows:-

Where there are two articles of the same description one imported, the other locelly produced - travelling in the same direction, and the lacal article is conveyed at a lover rate than the imported article, the rate on the local article is a "preferential' one." $Z$.

The Report of the Tariffs Inquiry Committee also condemed this sytem. Mhis principle has been dondemned wholeheartedly by practically every authority for the past 20 years. and we are not aware of any serious defence of preferential rates over having been edvanced." 2 .

The/..

1. Round Table No. 77 of 1929 "Railway Rates \& Boad CompetiEion, p.I87.

2. Quated from the Dept, Rly. Tariffs Inquirv Committan $n$ on 
The Report objected to the system on the grounds (a) that there is a danger of fraudulent declaration and (b) the inequality and ineffectiveness of such protection to local products. It cannot, the Report says, be effective for the inland S.A. product exported to the coastal towns and thus favours the coastal manufacturer at the expense of the inland manufacturer. The fundamental objection to preferential rates is, however, firstly that, even under the 'value of service principle' of railway charging, the ralue of service performed must be exactly similar for the transportation of exactly similar aticles; and seoondly, that any protection deemed necessary should be applied through protective duties and not through railway rates. It involves high prices for overseas products to the consumer and the other traffic has to bear the higher rates consequent on this concealed subsidy to the S.A. article.

The Admin. has abolished preferential rates on 170 articles since 1910 but there are still at present 70 articles, including sugar, grain, tea and tobacco, to which such rates apply.

The first assimilated tariff-rate sohedule of 1911 had 15 classes and the monopolistic power of the railways was used to put into practice an extensive system of subsidy and bounty, the so-called development pollcy. Very big reductions vere made on agricultural productions and requirements, certain industrial materials and export traffic. By 1916 the aggregate reductions since Union were estimated at $21,500,000$ p.a. "Distribution rates" vere introduced by the Central S.A.R. Into the two inland colonies in 1909. Goods forwarded from inland centres were charged at a rate equal only to the difference between the rates from the port to the forwarding and the destination stations. This gave the short-haul Inland trafic the full benefit of the 'taper' in long-distance rates. This system was applied throughout the Union in order to develop trade and industry at inland centres/.. 
centres.

The 1911 classification and subsequent amendments deliberately extended the epplication of rates per mile, diminishing, as the length of the haul increased, much more steeply than could be fustified by the reduction in the cost of carrlage." 1 .

In 1920 a completely revised rates classification reduced to nine (now ton) olesses and arranged scales of rates and fares in zones. W1th the fall in prices after 1920, reduetions in wes were confined to the low-rated agricultural and mineral trafic, and were spread over the longer distance rates.

"The general effect of the War increases and the postVar reductions was to widen still further the discrimination between high-rated goods and egrioultural and certain mineral trafle, and to subsidise still mare highly the long-distance traffic at the expense of the short-haul and high-rated consigments." 2. The two outstanding features of the rates struoture today are etill this wide disparity and excessive tapering.

The Tariff Inquiry Comittee found that the distribution rates were necessary because port rates 'taper' as distance increases and whout such distribution rates the tendeney would be for the distributing business now carried on by merchents in the interior towns to be diverted to the coastal towns. (One finds this attempt to counter-balance one subsidy by the grant of another again and again in the Admin.'s rate polfeyd such rates apply to traffic clessifled at Tariffe $1,2,3$ and 4 and are so caloulated 'as to secure, as far as possible, equality of opportunity betreen costal and inland merchants in direct route from the nearest port to final destination." 3. This/..

1. Round Table No. $77 \mathrm{pp} .188,189$

2. Round Table p. 190.

3. Dept. Tariffs Inquiry Committee p. 24. Such a system directly conflicts with the Law of Market Areas. 
This discrimination to overcome the disadvantages of geographical situation, ike the system of preferential rates, could only be maintained so long as the Administration exercised a complete monopoly. Such disorimination is also, of course, at the expense of the consumer.

The Committee differentiated a type of tariff, which is in fact a preferential tariff. Special rates are levied on certain S.A. manufactures and productions to enable the S.A. manufacturers to compete with the imported article at points where the distance from the nearest port is less than from the S.A. factory.

The principle is that if the distance from the S.A. factory to the destination is less than the distance from the nearest port, the S.A. produet pays the ordinary tariff rates. If the distance is greater, then the rate applicable to the imported article from the nearest port applies as a maximum on the S.A. article. In certain cases minimum rates are preseribed, otherwise for port toms the railage on S.A. products would be nil.

The Comittee did not regard this as a preferential rate and thus not open to the same objections. It did, however, point out certain undesirable features in the application of these rates, as for instance the fact that it is applied as between one S.A. factory and onother. Furthermore, it was of the opinion that when it is established that competition by the imported article with the S.A. product is no longer serious, the rate should be witharam. In view of these two objections, which the Committee itself made, it seems astonishing that it could arrive at the conclusion that this special rate was distinct from a preferential sate. The fact that discrimination is exerolsed as between one factory and another and that it is used to equalise the competitive price of the imported 
article, reveals clearly the protective or preferential basis of the rate. This special rate affords protection to the inland mufacturer and the preferential rate to the coastal manufacturer; and both represent an abuse of the railway tariff as a method for granting a protective duty, which, whotever may be the merits or demerits of pratection, should be applied openly through the Board of Trade and Industry.

Another system of special rates to and from factories applies to certain raw materials for manufacturing purposes. These rates are intended to aid the industrial and agricultural development of inland towns. The Committee stated that in general it agreed with comeroial interests in opposing discrimination in rates on certain articles according to the purpose for which such articles were to be used. The differential rates on coal according to the purpose to which it is to be put is indeed one of the worst features of the S.A.R. tariff polfcy. The Committee itself admitted that especially favourable rates are accorded to articles if they are to be used for agricultural purposes, particularly in irrigation.

Reference has already been made to the characteristic development rates. Such a rate is a spectally low rate created to build up the traffic of the particular article to which it is accorded. Such development rates have been applied extensively to agricultural products - a very good example is the export rate on maize.

In 1907 a flat rate of $10 /-$ per $2,000 \mathrm{lb}$. of maize was Introduced with the intention of developing an export trade In maize and providing traffic for a large number of empty trucks returning to the cosst. At that period the import traffic was much greater than the export traffic. The result has been an enormous increase in the production of maize and today the railways are hauling empty trucks from the coast. In July, 1924, the rate for maize in bags was Increased to 15/- per ton, but the rate for maize in bulk 
remained at 10/- a ton. The view of the Tariffs Inquiry Committee wes,

"It is, in our view, of particularly vital importance that nothing should be done to discourage the development of this Important trade. The maize farmer in S.A. is subject to speciel vicissitudes in the matter of drought and pests. He cannot rely on securing good crops oftener than once in several years." 1 .

The Committee did, however, advocate some increase in the rate once the position of the maize farmer and market prices had improved. It is obvious that this rate is completely unjustified. In so far as the 10/- per ton covered the aditional costs involved in the handling of the maize, this rate was an economic one so long as the maize merely filled otherwise empty trucks returning to the coest. It is simply an instance where the principle of joint costs applies in railway rating. Once, however, empty trucks had to be dram from the coast, the rate became completely uneconomic as the 10/- per ton would not nearly cover the total cost of transportation in both directions 1.e. both prime and supplementary costs. Moreover the increase in this traffic has been so great that the Admin. has been forced to maintain a much larger supply of rolling stock in order to aroid bringing other business, such as coal, to a standstill during the peak export period.

- In regard to the rate on export fruit, the comittee stated, 'with rare exceptions, the most unlucrative tariff In the S.A.R. is the rate on export fruit'. 2 . It involved the provision of special trucks and expeditions transport.

1. p.43 - In view of all his difficulties, surely it rould be far more kindness to help the maize farmer to find other occupations.

2. p. 44 para. 303. 
The committeo recommended that the railway rate for this traffio from Northern and Eastern Transvaal to Capetown should be reised by $10 /-$ to $27 / 6$ per $2,0001 \mathrm{~b}$. , with relative increases for distances below or above 1,100 miles.

Prof. Pigou pointed out in regard to development rates, "It is not a social gain if a rallway company, by temporary Iow prices, 'develops the traffic' from one distriet at the expense of destroying the traffic from another equally mell-situated district", 1.e. the temporary low prices mast lead to the development of a new demand and not merely a substitute for some other demand which is at the same time destroyed. 1 .

The argument for development rates is precisely the same argument used for the protection of infent industry, and like these infents they rarely grow up. The real test of a derelopment rate is whether, once the traffic has been built up, the speoially low rate can be raised to the normal level without destroying the traffic. It is safe to say that in no oase here in S.A. could the rate be so increased.

From the above it seems that every particular type or system of rate in the tariff policy of the S.A.R. has many defeots. But a more important criticism oan be made in general of the whole rating system. The fundamental fault has been to use the tariff as a means of directing the productive resouraes of the country into particular spheres and this has resulted in the diversion of Iimfted labour and capital from the more productive to the less productive ocoupations. It is protection through the railray tariff instead of through the customs duty and all the well-known arguments against protection apply with equal/..

1. Pigou: "Eoonomics of Velfare" Part II, Ch.XVI p.27I (4th ed.) 
equal force. Whet is more, the aims pursued by the covernment through the Railway Admin. are in large measure incompatible. It has already been pointed out that the tariff polloy seems to be a system of counter-balancing advantages and disedvantages.

It appears at times that it has been the deliberate aim of the Admin. to ralse the costs of stares required by the gold-mining induatry. Frankel has shown that $65 \%$ of the ordinary industrial requirements of the gold-mining indugtry in 1926 were charged at the three highest rates of the Railway Tariff and $37.8 \%$ at the two higher rates. Many of these articles were of relatively low value, and on the other hand meny articles of relatively high value of S.A. manufacture or origin, of S.A. products for export and of agricultural produce were (and are) classed in the Iower rate groups.

The great increase in low-rated traffic, that has followed on the introduction of the development rates, has, in fact, added considerably to the costs of working. It has involved the provision of speciel handing facllities, expensive and specialised rolling stock and heevier track. Fiven the Committe made the rather grudging admission, We feel, however, that at this stage of its development, the Railway Administration has now gone to the limit in the matter of granting Iow rates on low grade traffic and that the time has arrived, when, if the financial position of the Administration makes it possible to make rurther reduations in railway tariff, relief should be granted in the higher cless rates." 1 .

Thls survey shows just how vulnerable the financial position of the S.A.R. was in 1929 both to trade depression. and to the competition of road motor transport. This system 
of Intricate differential charging could rest only on a basis of complete monopoly, and once this basis was threatened, the instability of the finencial condition wes clearly revealed. The anxiety of the Administration to secure protection from competition of animal-drawn transport is eridence that even today the margin of profitable traffic at the highest rates is so small, as to make its position somewhat prearious.

The elimination of competition and the prosperity of the Union in recent years have made possible the resounding Railray Budgets of Mr. Pirow, but when this ware of prosperity emanating from the gold mines subsides, the warning of Prof. Frenkel, made in 1925, will become effective again:-

The present retes policy not only reises the cost of transport of the large traffic now being discriminated against, but leads to a cumulative inarease in the rates on all traffe, and will result ultimately in the railways beooming a burden on the taxpeyers of the Union. In the meantime the development of the interior provinces is restricted." 1 .

1. "Rail way Policy of South Africa since Union", p. 40 Conclusion No. 114 . 
THEORY OF RAILWAY RATES.

In the previous chapter the various types of rates charged by the Administration have been shown to be defeotive; in this ohapter the theory on which the Administration has besed these tariffs will be considered. I. The principles of railway rating were discussed in the first part of the Report of the Departmental Railway Pariffs Inquiry Committee. The agument follows the usual Ilnes of the 'value of servioe' prinoiple es enunciated by Aoworth and Stephenson in Flements of Railway Economies."

"Railway tariffs on every raflway of any importance are dominated by three fundamental facts, viz:(a) That oertain classes of traffic can only afford to pay rail way rates muoh lower than the average cost per ton mile of conveyance by ratl.

(b) That some classes of traffic can afford to pay railway rates considerably higher than the average cost per ton mile of conveyanoe by rail.

(c) Por reasons which will bementioned later, it is profitable business for a railway to convey additional traffio at rates considerably below the average total cost per ton mile, rather than lose such traffio by demanding higher rates then the traffic can afford to pay." 2 .

I. In this chapter I shall ignore the fact that the sysitem of differential charging has been complicated by polftical interference.

2. Dept. Rly. Tariffs Inquiry Committee, 1930 (U.G. 56 -'29) p. 3 para. 7 . 
The first two factors mentioned by the Comnittee merely state the obvious truth that when an enterprise has obtained the monopoly of the supply of any particular service, that enterprise oan obtain larger monopoly profits by charging differential prices than by levying a single monopoly price. The power to discriminate in the rates charged on different articles produoes a demand for transport that would otherwise not appear. Certain facts in the provision of transportation by a railway enable diacrimination to be practised successfully. The units of service are entirely non-tranaferable, 1.e. 'a railway's offer to chargo one price for a ton mile of transport service to copper merchants and a lower price to coal merchants cennot lead to any middleman derice, because it is physically impossible to convert copper into coal for the purpose of transport and afterwards to reconvert 1t'. 1 .

Secondly, units of demand are not easily transferred from one market to another, when the commodity concerned 1s something ready for final consumption, and when markets, between which the disorimination is to be practised, are distinguished acoording to the wealth of the purchasers (or value of the commodity). Provision of cheeper transport to coal merchants does not lead copper merohants to become coal merchants though it may lead merchents to move over into a faroured locality. I.

The very wide differentiation in rates on commodities of high and of low value is possible beoause as the Dept. Committee itself put it, "Iov grade traffic is extremely sensitive or responsive to increases or decreases in rallway tariffs, whereas high-grade traffic, such as clothing, boots and druggists' sundries, is not appreciably affected by railway rates." 2. 1.e. demand for transport by traffic 
of low value is highly elastic, the demand for transport by traffic of high ralue is inelastic.

This generalisation of Plgou, that discriminating monopoly yields a greater profit to the monopolist than simple monopoly, is the real reason for the validity of the third fact, (0), given by the committee. 1 .

The Committee, however, adrances the argument of the operation of 'Joint supply' in the service of transportation. It stated:- The explanation lias in the fact that the out-of-pocket expense which a rallway incurs in carrying additional traffic is very much less than the total average cost of conveyance per ton mile including interest and all fixed overhead charges; (because) an extremely large propartion of the total costs of a railway are 'fixed" and does not vary to any appreciable extent with ordinary fluctuations in the volume of treffic handled over the railway." 2 .

If, In fact, transport services are fointly supplied, then the differential rates of the Adminfstration might well be determined by simple competition rather than discriminating monopoly of the third degree. Equilibrium theory explains that, if two or more commodities are: jointly supplied, 1.e. one of them cannot be produced without facilitating the production of the other, the prices evolved by simple competition are so adusted to demand that the whole output of the commodities is carried off the market.

Taussig, emongst many other writers on railway economias, considered that joint supply did play a dominant part

1. "..... It is profitable business for a railray to convey edditional traffic at rates considerably below the arerage total cost per ton mile......"

2. p.3 pare. 9. This is the argument of 'Joint supply' ar 'joint products', though it is not clear whether the Committee intended it to be. 
In the determination of railway rates. Plgou makes a very careful examination of this olaim and concludes that it is not fustifled and that Taussig's argument rests on a misinterpretation of the nature of 'foint supply'.

According to Taussig, whenever a very large fixed plant is used for varled purposes, the influence of joint costs (or joint supply) exerts 1tself. He states that the capital sunk in a railway "seems equelly to aid in carrying on every item of traffic ..... Not only the fired capital of a railway, but a very large, in fact the largest part, of the operating expenses, represents outlay, not separate for each item of traffic, but common to the whole of it or greater groups of 1t." 1 . Joint supply, in Taussig's view, operates where a large mass of supplementary costs exlst together with the fact that the plant is used for varied purposes. While he admits that joint supply cennot eppear where the plant is used to produce a single, homogeneous. commodity, he believe that in regard to the conditions of demand the transport of tons of different things and the trensport of the seme thing for different purposes from one place to another are different, non-homogeneous services.

Pigou does not agree with Taussig in this interpretetion. The confunation of large, common supplementary costs with separation between the merkets to which their yield is supplied does not make railwey services joint products in this - the only significent - sense (i.e. In such wise that simple competition might be expeoted to evolve a system of dirergent prices). In order to be joint products each additional unit of investment, apert from/..

I. Quoted by Pigou 'Economics of Velfare', Part II, Ch.XVIII, p. 297 . 
from elternate use to facilitate the supply to oither market, cannot be used to facilltate the supply to one market without facilitating the supply to the other.

If merely used alternatively to facilitate the supply to elther market, with a number of competing sellers supplying transportation to sereral markets with different demand schedules - if the price in one of these markets is higher than in another, each individual seller will transfer his offer of service from the lower-priced market to the higher-priced market, and the process will tend to uniformity of price in all the markets. This result, under simple competition, holds good whether supplementary are large relatively to prime costs or not." 1 .

It sems clear, then, that in relation to competitive conditions the service of transporting goods or persons mat be considered as a single service. An exception must however be made in the osse of return Jaads. Return loads are supplied jointly with 'destination' loads, since any editional expenditure that is incurred in the movement of trucks must facilitate the supply of trucks in both direotions, 1.e. must necessar1ly increase the number of movement of truoks from A to $B$ and from B to 4 . This 18, as Pigou points out, true jointness and, under competition, the direotion for which the demand for trensport is higher would be charged at the higher rate than the return direotion for whlch demand is Iower. An instance has been given above of the maize traffic in its early stages.

The conolusion of Pigou is that, "This elemont of jointness is, howerer, of comparatively small importance.

Contrary/..

1. p. 298. This seems in fact to be the case with the raed motar carriers, who offered their services in the higher-priced markets. 
Contrary to the general opinion of writers on railway economics, the services supplied by railway aompanies are, in the main, not folntly supplied. Hence the conclusion emarges that, subject to the reservations set out in paragraph 2 (given belor), simple competition would, in general, evolve a system of equal ton-mileage rates for all comodities, whatever their character, and whether they are to be consumed at $B$ or to be sent from $B$ for some further part of a 'long haul'n $I$.

The theory of railway rating of the S.A.R. is, then, one of discriminating monopoly. The principle by which rallway tariffs would be fixed under competition is known as the 'cost of service' principle and is treated in detail by Pigou.

Except in so far as transport services sold to one set of purchesers are 'supplied jointly' with those sold to another set, simple competition would tend to bring about a system of uniform rates per ton-mile for similar services. For these services the level of the uniform rate would be such that the demand price and the supply price would coincide i.e. In the long run it would approximate to the cost of production of the service. This rate would be established purely for the service of transportation, extra services such as peking, carriage, special handling, etc. would be charged for additionally.

Plgou states that the circumstances and position of the railway would in part determine the actual level of this unfform mileage rate. For instance a high (relatively) rate would be appropriate for a line through mountainous country and where the trafic is irregular - the supply prices of all quantities of transportation would be specially high. Similarly where the demend sohedule is specially Iow (and conditions of decreasing supply price 
prevaill, as in sparsely populated regions, a high rate is appropriate. 1 .

Under simple competition there would be depertures from this uniform mileage rate in so far as buyers of a ton-mile of transport require other incidental services Involving cost. Generally it is more costly to carry small consignments rather than large as small consignments involve such expenses as separate colloction and delivery, separate handling, accounting at terminals and 'bad' loadIng. Such elements in the cost of handling as bulk, fragility, perishability, explosiveness; speed and regularity of service required; provision of special equipment are conditions which would also properly lead to varlations in the uniform rate.

The principle of 'tapering' may possibly be justified by the fact that a foumey which is part of a longer fourney Is less costly than the same journey as an isolated whole. This, states Acworth, is because Iong journeys get more mileage out of engines, wagons, train-staff, etc. than a number of short hauls with waits between; engines and wagons are better loaded and the line is more continuously utilised; expenses at terminals are reduced.

Plgou further notes the exception from a uniform rate of a similar service supplied at different times. He 1llustrates from the supply of electricity how the equipment cost is twice as much per unit to allow for 'peak' periods than it would be if a normal service was supplied. In order to carry peak loads at different times of the day

$$
\text { or } 1 . .
$$

1. This would seem to be the condition in South Africa where the population is scattered over a very large area and many regions are very thinly populated.

2. p. 294 . 
or In different seasons of the year, a railway company has to maintein a number of additional engines, carriages, extra staff, etc. $\mathbf{L}$. Though this would seem to infer that higher fares are warranted for busy hours or busy seasans, in fact workmen's tickets and excursion fares are supplied below the narmal price. Strap-hanglng is not so comfortable, however, as the corner-seat 1.e. the quality of the service is lover.

Lastly, the 'cost of service' prinoiple leads logloally in cartain circumstances to lower charges to people whose purchases of transport are continuous than to those who buy intermittently. The former oannot and the latter may contribute to the 'peakmess' of the load. In the case where special equipment has to be provided to supply the service, such differentiation is justified. This is because with regular use of the equipment, the charge per unit of service will be less than with infrequent use.

Some writers on railway rates, such as Praf. Hallsworth, while agreeing with Pigou that the ideal system of teriff flxing would be that of the uniform rate per ton mile of transport as determined by competition, point out that there would be great practical difficulties in actually arriving at this rate. Pigou himself is vell aware of the 'delicate adjustments' that will be necessary because of the incidental costs attaching to each service, and such considerations as the time and load factors. "It is therefore almays a question how near to the ideal it Is desirable to approach; at what point the advantage of getting closer is outralghed by the complications, inconrenience and expense involved in doing so."

2. But/...

1. This would seem to justify a rate above the average rate for the maize traffic today (because of the need to maintain extra equipment).

2. Ch. IVIII; p. 315. 
But the very importance of road motor transport is that it provides the competition in transportation which will enable the 'cost of service' principle to be realised almost automatically. The transportation industry must, it seems likely, almays remain a sphere of 'imperfect' or 'monopolistic competition'. The value of the motor lorry and the omnibus is that they aford some protection to the buyer of transportation from monopolistic exploitation.

In the chapters following it will be shown that the allegations, so frequently made, that competition is wasteful and engenders surplus capacity, have no foundation at all. Here the argument for monopoly, that it enables the production of an output which would not take place under conditions of simple competition, will be taken up.

Pigou states that in general simple competition will yield a larger output than monopoly (or competition results in the most fevourable distribution of resources in response to consumers' demands), but under a certain set of conditions the reverse holds good. These conditions are that while no uniform price can be established which will cover the expenses of producing any quentity of output, a system of discriminating prices can be evolved which will make some output practicable.

Suppose that it is desired to construct a railway from A to C, two large cities, passing through a country district in which is situated B. These cities, $A$ and $C$, are however already connected by road or waterway and the costs of transportation by road or weter are relatively lor. To meet this comptition the charge for goods from A to $B$, wich are destined to be carried on to $C$, must be so low that if applied to all the traffic between $A$ and $B$, including those goods to be consumed at $B$, the railway 
would not be constructed. Further the demend for transportation for goods between $A$ and $B$ to be consumed at $B$ is so small, that it cannot alone support the railway. That is if the railway is to be constructed, it is necessary that it obtains both the high rates for the small volume of Iocal trafflc between $A$ and $B$ and, also, the large amount of trafflc between the cities $\mathbf{A}$ and $C$.

It can also be shown that, in practice, unless discrimination is permitted in the ton-mile rates charged on different commoditios, no transport might be provided because there is no quantity of transport demanded for any particular commodity which would cover Its expenses of production. Pigou's comment on these exceptional cases is: "I have no quarrel with the proposition that these conditions may oocur in prectice. Principal Hadley and his followers, however, not content with demonstrating that they are possible, implicitly add, without argument, that they are typicel of the whole railway world and suppose themselves, therefore, to have proved that the value of service principle ought to be followed in the determination of all railway rates. Such an unargued inference is, pleinly,illegitimate. A cereful inquiry is necessary concerning the range over which conditions of a sort to justify the value of service principle are likely to extend in practice." I.

In practice, it is generally agreed that disorimineting monopoly cannot be soclelly advantageous unless decreasing arerage costs operate. Now it is true that the condition of decreasing everage cost is likely to be present in the oase of railway construction, because of the large size of the minimum first unft of investment and the large size of/.. 
of subsequent units of investment. It is obvious that the inftial costs of arranging for the rail transportation of a fow tons of traffic are practically the same as for a few thousands of tons - the seme heavy expenditure must be made for acquiring land, for surveying, for constructing bridges, tunnels and platforms, etc. This implies that the rallway is a form of investment in which the law of deoreasing supply price, or decreasing everage costs, acts strongly.

A second condition for discriminating monopoly to yield some output, when simple competition would yield none, is that the demend for the service or product must be elastic. The demand mist be elastic in the pertioular sense that at a certain stage in the demand sohedule, a small reduction in the price would cause a sudden ' Jump' in the demand ochedule. In practice it has been shom that when railway rates are at a moderate level, a small roduotion in the rates will cause this jump in the demend schedule to take place - a demand for transport arises in the case of commodities which would otherwise not have been transported at all.

The Departmental Railray Tariffs Inquiry Comittee put it as follows: "The principle of charging rates lower than the average cost per ton mile has resulted in an enormous expansion of railway business. As the total trafflc of a railway increases, the overhead fixed charges are spread over a greater number of units and this makes it possible to reduce the average level of the railway rates. The princlple of differentiating in railway tariffs according to the ability of the various classes of traffo to bear different rates has not only had the effect of 
reducing average transport costs, but has been of enormous benefit to the public in enlarging the areas of production, Introducing intensive competition by producers from different areas, and consequently lowering prices to consumers!

It must be admitted that if the only means of transportation service which could be provided was a rail way, then permission to base the rates on 'what the traffio will bear' may result in the provision of facllities, whereas the enforcement of a uniform price system would exclude certain demands for transportation and the demand would be Insufflclent for the rallway to be provided. But where there is a substitute for the railway available, in the form of a less expensive plant, then this substitute will be the most economicel method of providing for the smeller demand. The unit of operation in motor transport is a single one and the initial minimum unit of investment, and subsequent increments, is relatively very smell. Thus the road service might be used to meet the demand for transportation, which would be insuffialent to cell forth the supply of rail trensport unless disorimination in the tariff was allowed. 2. This exception to the generalisation, that competition equates the 'marginal social net product' and the 'marginal private net product of invested resources, is then of small/..

I. p. 4

2. Plgou asserts that in addition to the factors of deoreasing supply price and elastic demand schedule, a third condition must be fulfilled to ensure that disoriminating monopoly would evolve an output, were simple competition would not. The demand schedule and the supply sohedule must be related in a particular way. If the demand price is greater for a small quantity then the supply price, competition would evolve an autput, but if demand price is very much less than supply price, neither competition nor disarimineting monopoly would produce an output. The relation must, therefore, be an Intermediate one. 
smell practical importance. The very fact that the motor Iorry can move from one route to another and satisfy the Irregular and small demands for transportation is one of the economic advantages of motor transport; though the Road Motor Competition Commission seemed to consider it 'unfair' that road operators should pravide their services according to the availability of traffic and iransfer their activities from area to area according to the fluctuating density of traffic.' 1 .

If the road motor service gradually develops the traffic until the demand for transport increases to that extent, which would make possible the economies of decreasing average costs of rallway operation, then at this stage the rallway may be economically substituted for the raad service. Under this process of substitution, there would be no need to grant monopoly powers to the rail ways for the initial temporary period until the traffic had been developed by a discriminating tariff.

I. p. I8. 
"TASTERUL COMPEPITION".

Perhaps the most frequently repeated argument used to fustify the regulation and control of road motor transport is that the competition of the motor carrier with the railway involves waste. The Transport Group at the Congress of the International Chamber of Commerce held in Paris last year pessed the following resolution:-

co-ordination between road and rail is necessary in order to avold excessive competition which, by reason of the waste incurred ultimately involves the publio interest. ${ }^{l}$

The Road Motor Competition Comission stated, "Experience in other parts of the world tends to show that unregulated and unoontrolled competition results in an undue and uneconomic multiplication of services in certain areas and the neglect of others." $\mathbf{Z}$.

This view that the forces of competition which operate, when new investment or an invention causes a fall in the value, or earning capacity, of previously invested capital, are in themselves westeful is not confined to the sphere of transport only but is, in fact, a wide-spread belief today. Competition, it is said, causes waste by forcing the adoption of new maohines when producers would prefer to continue

$$
\text { using/.. }
$$

I. Quoted from Modern Transport", Feb. 2, 1935.

2. Report of Commission, p.19.

3. The modern enthusiasm for Economic Planning is due to a revulaion of feeling against the levelling effects of competitive forces. Planning has been defined by Sir. Basil Blackett as, 'a necessary corrective of the major rastes and frustrations arising from the unregulated impact of one economic activity upon another'. 
using the old ones. It leads to over-investment, surplus capacity and the 'premature' abandonment of productive equipment, which surfers a fall in value before it has lost the physical power to produce goods and services. "Some writers unaccustomed to mathematical analysis have imagined that, when improved methods of producing some commodities are introduced, the value of the marginal sooial net product of the resources invested in dereloping these methods is less than the value of the marginal private net product, because there is not included in the latter any allowance for the depreoiation which improvement causes In the value of existing plant; and, as they hold, in order to arrive at the value of the social net product, such allowance ought to be inoluded." I.

Pigau then proceeds to show why this view is incorrect. His argument, very briefly, is that the loss to the old producers through the reduction in the price of their produots is at least equalled by the gain to the consumers and the profits of the 'new' producers are a net social gain.

In so far as a valid oase can be put forward for the protection of vested interests on humanitarian grounds, even this is inapplicable to the issue of road motor competition with the State-owned rallways here in South Africa. Again and gain the desirability of protecting the $2143,000,000$ of public monies invested in the S.A.R. wes atressed; only Mr. Sturrock in the debate on the bill in the House of Assembly seamed to realise thet the very fact of public ownership made protection unnecessary.

$$
\text { "It /.. }
$$

1. Pigou "Economics of Welfare", Part II, Ch. IX, p. 188. 
"It may surprise the Minister to know that the view of some of us is that because this asset is State-owned, we can afford to look at the question of motor transport with complete impartiality. If the rallways were privately owned, we might hesitate to do anything involving losses, but if any losses are incurred now these losses will be borne by the whole of the country, and surely we can face these losses without difficulty." I. In other words since the railways are not the property of any section of the people, there is no case for the protection of capitel values so as to avold inflicting heavy losses on this particular seation.

The investment of capital in the motor carrier industry would take plece, with reasonable foresight on the part of the investor, only if it was possible to provide the same service of transportation, previously made available by the railways, 'at a smaller expenditure of current resources (i.e. at a smaller sacriffce of other possible users or to provide better services at an expenditure which is proportionately greater)'. 2. No unit of transportation formerly supplied by the railways will be supplied by road transport, except when the latter can produce this unit at a total cost smaller than the prime cost, which would have been involved in its production by the railways. This implies that every unit now supplied by roed must be sold at a price, which is less by as much as the whole of the net recelpts, after prime costs have been met, which the railways would have received from producing that unit. This proves that any Ioss to the railways is at least compensated for/..

1. House of Assembly 1930, Debates, column 3679.

2. Hayek, "Collectivist Fconomic Planning", p. 224. 
for by the gain to the consumer, and that the profit of the road operator is a net gain. 1 .

Mr. G. J. Ponsonby, in an article on "An Aspeet of Competition in Transport", in Economica, made a very able analysis of the cost stmacture of railways and of the real nature of the so-called 'wasteful competition'.

$\mathrm{He}$ commences by stating that the most significant charaateriatio of railway investment is the large propertion of it, which is incurred on assets, which have no value in other uses but at the same time do not lose teahnical efficienoy with use and do not require renewing. The expenditure on land, outtings, embankments and similar essets is speoialised and non-transferable. He asserts that the earnings in respect of this type of asset are in the nature of a rent or surplus.

"The practical significanoe of this lies in the fact that both costs, output and prices,are, generally speaking, independent of whether this surplus is realised or not. So that eren if the rate of interest on this form of investment vere to fall to zero, there would be no danger to the public, either of losing the facilities already being offered, or of having rates raised against such traffic as continues to pass ' In order to cover the now greater burden of averhead costs per unit of traffio'. For these capital charges are not overhead costs at all, but a resultant ourplus earned after having adjusted costs, output and prices to the company's best adrantage." 2. This/...

1. Pigou,Part II Ch. IX, The Social and Private Net Produot".

2. Heonomica Nov. 1835, p.45I. Such immobile forms of investment must be distinquished from certain lands, such as stations in the midale of a city and other similar specialIsed assets af a railway which have in fact other uses and oan be sold. The holding and use of such assets does constitute a cost, in the sence that the owners are denying themselves the annuity which is its value in the other uses. Where, however, the investment takes such a specialised form, that the equipment has no value in any other use, this cannot be regarded as a cost. 
When this investment in long-lived equipment was made, the revenue earned in excess of the shorter-run costs ras expected to meet the debt charges on this equipment for the forty years, after which it would be abandoned. As result of new inventions, this equipment is no longer capable of earning a surplus after 20 years. The level of revenue now earned per unit of service reflects the new price - established as the result of technical innovation - and the long-lived equipment will not be ahandoned so long as costs per unit of output lwhich is made up of all the shorter-run costs) remein below that price. It will no longer be used once the new means of transportation has enabled a pice to be charged which does not cover these shorter-run costs. Short-lived equipment is assumed to have a life of ten years and this equipment will remain in use so long as the prime costs are covered. Thus though the revenues actually earned may justify the continued use of both long-lived and short-lived equipment, so long as they cover the prime costs, they do not justify the renewel of the equipment.

Mr. Ponsonby sums up: thus the abandonment of capital or assets prior to when it was expeoted to remain profitably in service at the time of the investment, takes place: in the case of absolutely specialised and durable equipment only if the revenue earned was unable to cover all other costs, short- and long- run, not including any return on the capital invested in that durable form; long-lived equipment when revenues fail to cover the shorter-run costs incurred; shorter-lived equipment when revenues fail to cover still shorter-run costs.

The magnitude of the fall in the revenues which can take place without the abandonment of capital depends ion the relative importance of capitalisation incurred on behalf of each of various kinds of assets concerned. I. Where a 1.p. 455 
81.

large part is in respect of absolutely specialised essets, the fall would have to be correspondingly large before abandonment. Where interest and depreciation on lang-Iired equipment is high relative to total expected level of earnInge, then within the life of these assets the fall would have to be relatively large before this equipment would be abendoned.

Thus it seems that in South Africa, where the capital investment in immoblle assets, which are absolutely specialised in their use, has been heary and where the debt services on long-lived equipment is relatively high, the danger of a fall In the revenues of the Administration, as a result of road motor competition, which would necessitate the rational abandonment of equipment, seems small.

The effect of protection being extended to the railways is to oheak the fall in revenue and thereby enhance the value of durable, speoialised assets as it enables a larger surplus to be earned over long- and short-run costs. Proteation may maintain revenues so as to fulfil the original anticipations of interest and depreaiation on equipment, long- and short-lived. Abandomment of equipment may be postponed and there is the danger that at the time of reneral, the 'protected' equipment may be replaced by similar equipment instead of by the new means made arailable by teohnical adrence.

nThus under proteotion capital and labour may be drawn Into re-rendering services, for which there is a less urgent demand than for other ner services". I. There is then a waste of resources, but the weste is the result of proteation and not of competition. The apparent

'wastes*/.. 
'wasteg: of competition were in faot incurred at the time when the investments were made in the railways. These wastes arise from 'over-investment' in the railways through the failure to estimate correotly the future demand for raflway services. The competition of road motor transport was not foreseen. This failure to realise the ruture possibilities and efficiency of the motor carrier industry resulted in an over-estimation of the revenue-earning life of capital investments and in iadequate provision for the obsolescence of assets. Thus the 'alleged waste' does not take ploce at the time of the introduction of the improved faoilities of motor transport but at the time when the now partially obsolete assets of the railways were originally acquired. The introduction of the new methods merely makes olear the previous waste, which arose from the incorrect anticipation of the future demand for the services of the rail way.

"When new facilities (covering all their $\infty$ sts and incorporating the latest technical inventions) are provided which render older facilities incapable of meeting debt services to the extent that wes expected of them, it is not the introduction of these new facilities that constitute the waste. Rather their introduction, by proving the essential unisdom of the form and extent of previous investment and polioy, discloses the fact that there has been werte, and no amount of protection can prevent that." 1 .

In South Africa where political intervention has played such a large part in direoting investment, the waste that showed itself with the emergence of competition naturally seemed extensive. The legalised protection has maintained and expanded the revenues of the railways but it cannot obviate the waste of those misconcelved operations carried out many years ago. The estimation of the future course of/.. 
of demand for railway services was in error. As a result the development of motor transport, and this change in demand, in the absence of proteation, would have diminished the present capltal value of the railway. Since the railways are State-owned, no hardship from the fall in capital value results - no sectional interests of ownership are affeoted. The railways would have continued to render services at prices, which were previously unacceptable, until the revenues of the railways fell to that extent when abandonment of assets would have taken place as outlined above. 
"IN IXXCESS OF PUBLIC NEHEDS, $"$

Another often-heard argument for the restriotion of road motor transport, is that in the absence of control, the facilities are provided 'in excess of public needs'; or, again, unrestricted competition leads to 'an unnecessary duplication of services'. This is merely anotherprariant of the theme of wasteful competition, but perhaps deserves special mention in view of the widespread bellef that the members of a regulatory board are more capable of arriving at the true needs of the consuming public than is the free interplay of economic forces.

If absolute freedom of entry was permitted into the motor cerrier business, resources would be invested up to that point at which the return on the investment is at 2oqual to the return from alternative investments. Under a market economy, production is guided by the comparison of the market price of the final product and the prices to be paid for the required factors of production. The oriterion of profitability is the best available test of whether the 'benefits' derived from a particular investment outweigh the 'sacrifices', or not. The prioe wich consumers will be willing to pay for transport services is a refleotion of the benefits to be derived and the terms on whioh people will provide the services are a measure of the sacrifices. If there is a favourable margin, 1.e. If profits are made, resouroes of capital and labour will be attracted. The increase in output, or supply of transport services, may tend to a reduction in 
the least cost to the community. In this way overlapping, redundant or unnecessary services would disappear, and each form of transport would convey just those passengers and goods for which it was best suited. Such a division of traffic betweendifferent modes of transport would be determined by the demand of those who required it and the facilities offered by those who provided it, while the incidence of cost to the commity should be such as not to involve the subsidisation of any one form at the expense of the others." 1. The comment made on this in the Final Report of the Royal Commission on Transport was:- "But as things are today, is such a state of affairs, or even any approach to it, practicable? Tho is to decide what goods should in the national interest be sent by rail, road, canal or ship?"

Clearly no one person can make such a decision which would attain the 'ideal division of function', but a very large number of persons, constantly comparing prices and costs and constantly attempting to increase output and reduce costs, would 'automatically' approach to the ideal. The decisions of any board established for the purpose of deciding what constitutes 'the requirements of the publio' must then be purely arbitrary; competition is the only non-arbitrary method of determining the needs of the public. No one would wish to deny that owing to the incorrect anticipation of the future course of demand for his services, an entrepeneur may invest capital which does not yield the expected return. In this way it is possible to conceive of over-investment in the industry and the provision of transport services in apparent excess of the public requirements. But if the selective force of bankmuptcy is permitted to/..

1. "The Future of Rail Transport" in the Economic Journal, Dec, 1934 - article by H. H. HaIl sworth, pp. 553-554. 
Gapetom-Sea Point route. 1. In the halcyon days before the lacal transportation board appeared at Capetown to make up the minds of Sea Pointers by what means they really wished to trevel to Capetown and how much they wanted to pay (i.e. before 1930), it was possible to obtain a 'bus or a tram at half-minute intervals and on oertain 'buses the fare was as $10 \pi$ as 2d. This state of affairs, the local board dealded, was directly contrary to the true interests of the Sea Pointers. The board began by refusing certificates to about half the 'bus operators, in particular those who provided the service at the 'unecanomic fares' of 2d. and 3d. Finally a monopoly wes acquired by the Capetown Tramays and Bus Company, who bought out the few remaining independent operators. Still zealous in the interests of the Sea Point public, the board proposed a minimum fare of 3d. on the 'buses which 'enabled' the public to use the trams instead and thereby permitted a number of 'buses to be withdram.

mhe local board has found that on routes served by parallel services, 1.e. 'buses and trams controlled by one operator, the imposition of a minimum 'bus fare is advantageous to the operator as well as to the public." 2.

It is not difficult to agree that the grant of the most complete monopoly powers to the Company has been advantagrous to it, but after listening to the comments af Irate Ses Pointers, with Hobson's oholce between waiting, sometimes 10 minutes, for a 'bus ar travelling by a slow and very notsy tram, I feel that the advantage to the public

$$
\text { is/.. }
$$

1 .

I speak here from actual exparience.

2. Report for year ended March, 1935 (U.G. 40,1935) p. 25. 
is not quite so conspicuous.

The Road Motor Competition Cormission asserted that, "the competition leads to the cutting of fares and rates for transport service and, while the public may temporarily gain by uneconomic rate-cutting - and this is a point made much of by the advocates of free competition - in 1 the end if must pay. It is almost the invariable experience after a rate war that the survivors so frame their tariffs as to recoup themselves for losses temporarily sustained."

The Commission seems here to have been groping after the idea of 'agressive selling' or 'monopolistic dumping', i.e. a particular enterprise attempts to obtain an ultinate monopoly by charging prices below cost so as to eliminate competitors. 2. It is hardly likely that small motor carrier operators deliberately undercut railway rates and suffered losses with the intention of driving the S.A.R. out of the transportation business and then making large profits by charging monopoly prices. There was, in fact, some danger of 'uneconomic' fares and rates being fixed but not by the road operators. Instances can be found where the Administration deliberately undercut the prices charged by private operators with the intention of eliminating such operators and then restoring the old rates. Perhaps the donkey-vagon drivers, who undercut the Administration in the carriage of petrol, are, in fact, waging a rates war with the S.A.R.

In fact, of course, the prices charged by private operators have been sufficient to cover their costs.

1. p. 20 .

2. This so-called "cut-throat competition" is really the expression of monopoly. The monopoly deliberately charges prices below cost where it experiences competition so as to eliminate this competition and recoups these losses from its monopoly gains, where it has no competition. 


\section{CHAPTER VII}

SOME GENERAL CONSIDERATIONS.

It seems to be very easily assumed by those who favour the restriction of competition that, firstly, there is a definite amount of transportation service demanded by the public and that any traffic that the motor carrier obtains Is at the direct expense of the railways, and secondly, that the sphere of operation of both forms of service is mutually inclusive.

The first is another variant of the work-fund fallacy. Any traffic that goes by the motor lorry and the omnibus is regarded as necessarily a diversion of traffic from the railways. In fact the road service has developed a certain amount of 'new' traffic. Many charabanc excursion tours cater for a class of passengers, who did not and could not make similar excursions by rail. Such tours are often conducted through routes where the railway has not yet penetrated. In regard to goods services, the trafric might be quite insufficient to permit of the profitable operation of a railway service but is still sufficlent to give remunerative employment to a motor vehicle. In certain cases the road permits the carriage of goods through districts in which natural barriers have prevented the construction of railways. Road motor services have proved of particular usefulness in the transport of wool and deiry products.

In so far as the Road Hotor Competition Commission admitted that the road motor might provide supplemental and developmental services, it claimed that such services

$$
\text { had/.. }
$$


had been provided by the Road Services of the Administration rather than by private enterprise. Private operators confined their activities to waiting until the traffic had been slowly built up by the railways, and then slipped in and captured this traffic by undercutting the railway rates. It is true that private carriers have not been conspicuous in the development of services, which were not al ready provided by the railways - though there are certain exceptional instances. But there is a very good reason why private enterprise did not engage in 'opening up the country'. It has been explained at some length above that the rates for certain classes of traffic were so exoeptionally high that road operators could carry these goods at lower rates and obtain substantial profits. Resources were attracted at first to obtain the relatively high rate of return available in this particular form of enterprise, but once the rate of return had declined there, if developmental services offered opportunities of profitable investment, then there is little doubt that private enterprise would have engaged in the provision of these developmental services.

Rail transport is at the moment clearly unrivalled for long-distance transport. Then the National Roads Plan has been carried through, the potential sphere of road transport would be greatly extended but it seems likely that for some considerable time, the conveyence of raw materials for industry and of heavy, bulky consignments will be undertaken by rail. In South Africa the motor Iorry is definitely unsuited for the handing of heavy, long-distance goods traffic. Road speeds are in general considerably less than rail speeds for the longer distances. It is improbable, too, that any private firm in South Africa 
are willing to pay, where necessary, a higher fare than is charged by the railway for the comfort of frequent services and favourable location of stops.

There is no intention to lay down arbitrarily the respective spheres of road and rail transport. But as conditions are today in South Africa, if no restriction was placed on the operation of road motor services, it indicates the limits in which there would be effective competition and substitution of the one form of transpart for the other. In England competition was severe because of the excellence of the roads and the railways and the prevalence of the short haul; in America the motor carrier industry has been stimulated by the low first cost of vehicles, by fairly low motor taxation and the higher speeds possible on its solidly constructed highways.

In South Africa the competion for the suburban passenger transport in the larger tows would, in the absence of control, certainly be severe. But the eliminination of passenger road transportation is clearly a flagrant frustration of the public's preferences. If the Motor Carrier Transportation Act had been passed a couple of years earlier, there is no doubt that the Sea Point railway line would have still been in operation and residents would have been forced to use it by the suppression of competitive road transport. The great length of the 'Iong heul', the relative difficulty of obtaining return loads and the very bad conditions of South African roads would seem to preclude the development of competitive road transport on a large scale. In so farlas there was competition for goods traffic over distances longer than about 30 miles, it developed solely because of the peculiar rate structure of the S.A.R. 
The chief conclusion that emerges from the survey of transport conditions prior to $1929-1930$ is, I believe, that the competition of road transport for goods services was only made possible by the relatively high tariffs on certain commodities. If the railway tariff had been modified and railway menagement freed from those influences, which prevented it from operating on normal 'business Iines', then the railways would have had little competition with which to contend. Protection of the railways has made permanent this rates policy, which represents some of the worst abuses of discriminating monopoly, and has further deprived the community of the benefits of technical pragress by eliminating the motor carrier from that sphere in which it could have been economically substituted, even if the rail ways had charged according to the 'cost of service principle'. I.

A point made by supporters of control of transportation services is that a certain distribution of economic resources has/..

1. The Dept. Railway Tariffs Inquiry Committee recommended three schemes to meet the competition of road transport on short distances. Scheme A provided that the rates as established in 1929 for goods in classes $1-6$ for the distance of 200 miles should be applied per ton mile to all distances between 1 and 200 miles. This would abolish the loading of the rates for distances of less than 200 miles as compared wlth rates for 200 miles. Moreover so long as the total distance is less than 200 miles, the 'splitting' of the branch Iine rate would not increase the rate. This Scheme, the committee estimated, would mean a sacrifice of revenue of 2350,000 p.a.

Scheme $B$ was to reduce rates for all distances between 250 miles to same rates permile as apply at 250 miles. The revenue yielded would be $\$ 446,400$ p.a. Scheme 6 was to reduce rates for all distances below 300 miles to the same rates per mile as apply at 300 miles, yielding $2588,000 \mathrm{p} . \mathrm{a}$. In revenue.

It considered that such very minor modifications of the railway tariff would at least counteract the further diversion of traffic. Pp. 18-19 of Report. 
has been established on the basis of the present system of railway rates. Investment in certain industries such as agriculture (e.g. maize farming) and location of factories has been based on this differential railway tariff. Transportation costs are an important element in the cost of production to the person who is contemplating the investment of cepital. It is true then that any sudden changeover from the present 'subsidy' rates to rates based on the 'cost of service' principle would have very seriously disorganising effects on the established structure. This is, however, merely a recognition of the need for the application of the 'principle of gradualness' in legislation and in no way invalidates the theoretical case against the restriction of competition. Horeover it seems reasonable to suppose that the modifications of the railway tariff, which would be induced by unrestricted road motor competition in this country, would not be of such a violent nature as to disrupt the present distribution of resources and location of industry. It would prevent any further maldistribution, based on 'uneconomic' costs of transport and eventually bring about a rational distribution of capital in so far as transportation costs are a determining factor.

The third reason that was given by the Minister of Railways, in introducing the bill to provide for control, was that the wage rates and privileges of the railway staff would be affected. No lengthy discussion can here be entered into in regard to the Administration 'civilised labour policy' but some mention can be made of its effects. When a department of state pays wages above the market rate, it attracts labour from private enterprise. 
Because of the increased labour cost, the price of the final service will be higher than otherwise. Furthermore this wage-rate can only be maintained if some restriction is placed on the number of entrants into the department's service. On the S.A.R. the 'civilised labour policy' has resulted in the throwing out of the Administration employment of large numbers of non-furopeans. This has had the effect of further depressing wages in the market for unskilled labour. Unskilled white labourers drifting in from the farms have been faced with this unduly low wage, and thus the Government's attempt to solve the poor-white problem by a 'civilised labour policy' has, in fact, tended to increase the magnitude of the problem.

Even if the 'principle of gradualness' is again recognised, competition would hardly have acted so swiftly as to suddenly cause the displacement of numbers of the railway's civilised labourers.

of all the reasons put forward for the control and restriction of motor carrier competition, only one has real validity. "In so far as road transport has not borne its appropriate share of road maintenance and construction, then it could well be claimed that there has been waste. For the whole industry, through the instrumentality of public finance, may have been thus able to develop beyond that point at which marginal returns are equal. It has been established out of public funds." 1 .

TABLE /..

1. G. J. Ponsonby - "An Aspect of Competition in Transport", p.448 footnote. 


\section{TABLI VII}

FXPENDITURE ON ROADS \& BRIDGES IN THE UNION. 1 .

\begin{tabular}{|c|c|c|c|c|c|c|}
\hline & & & & & & \\
\hline & $1929-30$ & $1930-31$ & $1931-32$ & 1932.33 & $1933-34$ & $193 i-35$ \\
\hline \multirow{2}{*}{ 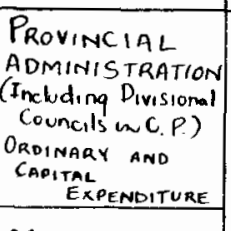 } & E & $E$ & $Z$ & $\not$ & $Z$ & \multirow{2}{*}{$\begin{array}{c}Z \\
2,340,776\end{array}$} \\
\hline & $2,150,779$ & $2,234,235$ & $2,167,677$ & $1,830,242$ & $2,061,113$ & \\
\hline 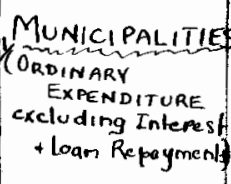 & 874,243 & 823,038 & 793,574 & 822,432 & 832,079 & $x$ \\
\hline \multirow[t]{2}{*}{$\begin{array}{l}\text { CAPITAL } \\
\text { EXPENDITURE }\end{array}$} & 687,474 & 739,793 & 835,636 & 923,480 & 980,211 & $x$ \\
\hline & $3,712,496$ & $3,897,066$ & $3,796,88$ & $3,546,154$ & $3,873,403$ & $\times$ \\
\hline
\end{tabular}

3. Not arailable yet

\section{TABLE VIII}

REVENUE COLLECTED FROM MOTOR INDUSTRY IN UNION. 2.

\begin{tabular}{|c|c|c|c|c|c|c|}
\hline & $\begin{array}{c}1929-30 \\
z\end{array}$ & $\begin{array}{c}1930-31 \\
z\end{array}$ & $\begin{array}{c}1931-32 \\
Z\end{array}$ & $\begin{array}{c}1932-33 \\
z\end{array}$ & $\begin{array}{c}1933-34 \\
1934-35 \\
z\end{array}$ \\
\hline $\begin{array}{c}\text { RROYIICIAL }_{\text {TAXATION }} \\
839,156\end{array}$ & 926,319 & $1,016,435$ & $1,138,161$ & $1,213,913$ & $1,497,713$ \\
\hline IMPORT $_{\text {DUTIES }}$ & $2,120,476$ & $1,57,593$ & $1,948,727$ & $1,936,368$ & $2,447,107$ & $3,365,587$ \\
\hline & $2,959,632$ & $2,497,912$ & $2,965,162$ & $3,074,529$ & $3,660,020$ & $4,863,300$ \\
\hline
\end{tabular}

It has proved impossible to obtain acourate information for the years prior to 1929-30 but the above tables give details for the expenditure on roads and bridges in the Union and the revenue collected in taxation and customs duties from the motor industry for recent years. These figures are strong evidence that the contribution of the motor industry towards road construction and maintenance

1. Supplied by the Dept. of Census \& Statistics. In the case of Natal municipalities expenditure on all public works is included.

2. Special Report Series of the Dept. of Census \& Statistios, Nos. 91 \& 97. 
( has indeed been adequate in the last few years at least. As it is only within this period that the Union Government has given its attention to the improvement of the Union's road system, there is justification for believing that prior to 1929 the proportionate contribution was even higher. The statement of the Chairman of the Road hotor Competition Commission during the course of the evidence is not borne out by the facts. He stated: "The revenue derived from direct road taxation and from Ilcence fees, etc. on the motor vehicles in operation in this country fells far short of the expenditure necessary to maintain, and in many cases to reconstruct to the higher standard modern transport requirements demand, the road system in South Africa."

Furthermore, as the general community benefits directly and indirectly from road improvements, it would be unreasonable to demand that the motor industry bear the whole cost. Certain other reasons for the necessity of control were given by a member of ane of tre local boardsin a personal interview. He said that there were many cases on record of operators purchasing second-hand vehicles for a few pounds and providing erratic services. The vehicles were not road-worthy and when accidents occurred, these owners were not able to pay out compensation. This is, however, an argument for the enforeement of compulsory insurance, which was in fact written in to the original act but which was subsequently withdrawn. Moreover it seems unlikely that such transport agencies would have obtained much custom. Many of these owners, too, bought their vehicles on the hire-purchase system but with no intention of actually paying the instalments. Thus their charges did not include any contribution towards the cost of 
equipment. This, again, is no economic argument and motordealers could surely have been trusted to take care of themselves.

Another'non-economic' reason, which the board-member advanced, has considerable practical importance. Rival 'bus oompenies, in attempting to gain passengers, instructed their 'bus drivers to ignore the ordinary traffic regulations. On the sea Point route, for instance, speeding and cutting-in resulted in a great number of accidents. Here, too, the remedy would seem to be stricter control by traffic authorities rather than legislation to reduce the number of 'buses. In any case this argument is relevant only to municipal passenger transport. 


\section{CONCLUSION.}

The reasons that have been advanced for the regulation and control of road motor transport have been examined and shown to be fallacious. The restriction of competition cannot be justified on the grounds that it is in the Interests of the public or in the Interests of the railways, for the railways' interests are, in South Africa, the public's insterests. In conclusion it remeins for a brief statement to be given of the present and probable future position of transport in this country and to put forward certain suggestions, designed to secure a cheap and efficient transportation service.

A member of local board stated that the most important result of the activities of the central and local boards had been the establishment of a co-ordinated system of transport. He said that he himself believed in the system of 'controlled monopoly' . Co-ordination means that competition of road services with the railways and amongst the road operators themselves has been eliminated. Motor carrier services have been diverted to serve as supplemental services to the railways. Thus the position is to-day that the monopoly price is the price for almost every piece of transportation service provided. A member of the local board said that the board welcomed the state of affairs today in Capetown, where the one passenger company has absorbed every other former transport service but one. It is not in any way surprising to find that at the Transport Conference held at Pretoria in September, 1934, 
the representatives of 'certified' agencies heartily approved of the existing legislation. But this is hardly evidence of the general social benefits of restriction of entry into the industry.

The future seems likely to see the extension of the present protective legislation to bring within its control the operations of animal-dram transport and taxi-cabs. Apparently the profitable margin of traffic of the S.A.R. is so small that the loss of a certain amount of petrol traffic to the donkey-ragons is sufficient to ruin the Administration. It is not impossible that if the number of private motor-car omners continues to inorease at the same pace as it is today, that the Administration and established services will demand that the use of cars by their owners be curtailed:

The Union Government has shown its intention to maintain a practical monopoly of the business of transport by acquiring control of commercial air transport. The Minister of Railways, Mr. Pirow, in referring to the loss that the Administration annually sustained as the result of operating the airway service, frankly stated: We must accept and carry this temporary loss if we wish to protect ourselves against competition. If we do not carry on the service some private company will do it and will eventually reap the benefit.

The great social benefits of transportation are obvious. To a country such as this with its widely-scattered, sparse population and vast distances the provision of an efficient and cheap service of transportation is of vital concern. It is of special importance that the adition to melfare, material and immaterial, of technical progress and cost- 
reducing factors in this sphere should not be foregone. Control and regulation have deprived us of increased efficiency and the reauction in transportation costs. Protection and co-ordination have brought us monopoly and monopoly means the divorce of social and private advantage. How are we to secure in transport the full benefits of the ever-cheapening processes of production, which hare been called social progress?

In South Africa the immediate need, as has been repeatedly stressed, is to separate the management of the railways from political intervention. The more glaring defects of the present administration may be removed through remedial legislation. The obvious requirement is the establishment of a really independent Railways and Harbours Board, which would ensure that those provisions of the South Africa Act, designed to safeguard railway users against the increased cost due to politically-imposed burdens, would be enforced. Control of the railways should be vested in the Board, which should not act as an advisory body to the Minister of Railways. The voting power of all members 'should be equal and qualifications of members should preclude the appointment of the representatives of vested interests. If Parliament should desire that any particular industry or section of the people should have the benefit of especially low transportation costs, the benefit should take the form of a direct subsidy, the cost of which would fall on the whole community and not on the railway users.

To secure that the fullest advantages are derived from technical advance, the Road Transportation Acts should be repealed and complete freedom of entry into the transport industry be permitted. It is, however, advisable that operators should be compelled to provide adequate insurance against accident and that they should not be allowed 
to disoriminate in their charges as between different purchasers. A careful investigation should be carried out to ascertain whether road transport is bearing its proper share of the cost of road construction and maintenance and taxation levied accordingly. 1 .

The competition of private operators with the railways and of the private operators amonst themselves would result in the cost of transportation approaching the ideal of the 'cost of service' principle. Under competition there could be no such thing as 'surplus capacity', as any operator who did not cover his costs would either move out of the business or go insolvent. Investment would be restricted only by the possiblity of larger returns from the alternate uses of labour and capital in response to society's demands. Professor Lionel Robbins, in commenting on the proteotion afforded to railways, remarked: "If we want to preserve railways which are unprofitable in the present condition of demand, we should subsidise them as ancient monuments." It seems unlikely that even if road transport were permitted to operate without any restrictions, it would become necessary to commemorate the S.A.R. but the irnportance of the private carrier to the community lies not so much in his possible usurpation of the railways, but in his providing a cheok on monopoly.

1. If all the revenue obtained from the motor industry was handed over to the National Roads Board, it seems that the contribution of road transport would be more than adequate. 
TABLE ILLUSTRATING EFFECT OF BUS CONPETITION ON THE RAILTAY LINE BETISIN CAPETOWN AND WYNBERG.

Amount of Revenue and No. of Passenger Journeys on the Capetown-Hynberg railway.

\begin{tabular}{|c|c|c|c|c|c|c|c|c|}
\hline MoNTH & 1921 & & 1927 & & 192 & & 192 & 9 \\
\hline & $\begin{array}{c}\text { No. of PASSENGER } \\
\text { JoURNEYS }\end{array}$ & $\begin{array}{c}\text { Revenue } \\
£\end{array}$ & $\begin{array}{c}\text { No. of PASSENGER } \\
\text { JoURNESS }\end{array}$ & $\begin{array}{c}R_{E} V E N U E \\
£\end{array}$ & $\begin{array}{c}\text { No. of PASSENG ER } \\
\text { JOURNEYS }\end{array}$ & $\begin{array}{c}\text { ReVENUES } \\
f\end{array}$ & $\begin{array}{c}\text { No. of Passenge: } \\
\text { Journeys }\end{array}$ & $\left\{\begin{array}{c}\text { REVENUE } \\
z\end{array}\right.$ \\
\hline January & & & $1,477,566$ & 4,355 & $1,269,838$ & 11,484 & $1,249,940$ & 10,881 \\
\hline FEBRUARY & & & $1,441,493$ & 13,328 & $1,159,941$ & 9,748 & $1,222,746$ & 10,043 \\
\hline MARCH & & & $1,542,480$ & 14,502 & $1,213,285$ & 10,482 & $1,301,827$ & 10,974 \\
\hline APRIL & & & $1,524,514$ & 14,375 & $1,206,765$ & $1 / 192$ & $1,306,105$ & 10,760 \\
\hline MaV & & & $1,533,413$ & 14,474 & $1,235,251$ & $(0,473$ & $1,291,002$ & 10,735 \\
\hline June & & & $1,496,053$ & 13,956 & $1,142,294$ & 9868 & $1,246,337$ & 10,586 \\
\hline Juey & & & $1,426,790$ & 13,320 & $1,275,748$ & 10,838 & $1,342,788$ & 10,781 \\
\hline August & & & $1,456,800$ & 13,038 & $1 / 88,607$ & 9,363 & & \\
\hline SEPTEMBER & & & $1,402,875$ & 12,525 & $1,231,900$ & 10,421 & & \\
\hline OctoBER & $1,520,210$ & 14,473 & $1,392,190$ & 12,708 & $1,360,464$ & $1 /, 815$ & & \\
\hline November & $1,604,712$ & $/ 4,535$ & $1,328,434$ & $1 / 3758$ & $1,280,879$ & 10,742 & & \\
\hline$D_{E C E M B E R}$ & 1,502,747 & 14,967 & $1,262,209$ & $1 / 3584$ & $1,270,572$ & 11,167 & & \\
\hline
\end{tabular}

This Table is obtained from Appendix IV of Memorandum submitted by the General Manager of the Railways to the Commission on Road Motor Competition. See Volume III of the Evidence.

The electric service was introduced on this line in July, 1928, and extended in September, 1928. Fares were revised from the lst April, 1929. 
At the Southern Africa Transport Conference held recently in Johannesburg, the following resolution regarding competition in transport was passed:

"It was argued that the railways were a vital factor in agricultural development and in preserving the primary industries of any country; that the existing world-wide railway policy of charging high rates for valuable traffic and lower rates for primary products was essential to stimulate and maintain primary production, and that this policy was seriously imperilled where uncontrolled competition by other forms of transport was allowed." Cape Times, Sept. 15, 1936.

This is further evidence of the fact that the real aim of restrictive legislation is to preserve a particular system of railway rates. 